This is an electronic reprint of the original article. This reprint may differ from the original in pagination and typographic detail.

Author(s): Hundal, Shabnamjit

Title: $\quad$ Busyness of audit committee directors and quality of financial information in India

Year: $\quad 2016$

Version:

Please cite the original version:

Hundal, S. (2016). Busyness of audit committee directors and quality of financial information in India. International Journal of Business Governance and Ethics, 11(4), 335-363. https://doi.org/10.1504/IJBGE.2016.10003075

All material supplied via JYX is protected by copyright and other intellectual property rights, and duplication or sale of all or part of any of the repository collections is not permitted, except that material may be duplicated by you for your research use or educational purposes in electronic or print form. You must obtain permission for any other use. Electronic or print copies may not be offered, whether for sale or otherwise to anyone who is not an authorised user. 


\section{Busyness of Audit Committee Directors and Quality of Financial Information in India}

Shab Hundal

JAMK University of Applied Sciences and

University of Jyväskylä,

Jyväskylä, Finland

Shabnamjit.hundal@jamk.fi

$\underline{\text { Shabnamjit.s.hundal@jyu.fi }}$

Abstract: The audit committees, as a part of the internal corporate governance mechanisms, play an important role to enhance the financial reporting quality. The busyness of audit committee members of a firm in boards and committees of other firms can affect its independent functioning, ceteris paribus. The current study examines, first, the association between multiple directorships of audit committee members and quality of financial reporting in India, second, whether endogenously determined busyness limits of busyness of the audit committee members provide better insights than those exogenously mandated by regulators. The study finds that endogenously determined busyness limits of sub-samples and the full sample explain the association between multiple directorships of audit committee members and financial reporting quality in a better way than those stipulated by regulators. Further, a lower (higher) level of busyness of audit committee members enhances (deteriorates) financial reporting quality of firms.

Keywords: Financial reporting quality, busyness of directors, agency theory, resource dependence theory, India, accruals, audit committee, reputational capital, extended interlocking, spline regression.

Biographical notes: Shab Hundal is a Senior Lecturer of Strategic Management-JAMK University of Applied Sciences and researcher at University of Jyväskylä. His principal area of research is in the field of Corporate Governance, Corporate Finance and Financial Reporting Quality. 


\section{Background}

There is an extensive body of research exploring the association between the independence of audit committee members and the financial reporting quality (Abbott et al., 2000; 2004; DeZoort et al., 2002; Bedard et al., 2004; Raghunandan and Rama, 2007; Sharma et al., 2009; Dhaliwal et al., 2010). An important determinant of the independence of audit committees is the phenomenon of audit committee members serving on multiple boards. However, the association between the independence of audit committee members and the financial reporting quality is relatively less researched (Sharma and Iselin, 2012). In the current study I explore, first, the association between the phenomenon of multiple directorships (also referred as 'busyness' in the current paper) of audit committee members and the financial reporting quality, measured by the discretionary accruals, by analyzing data of Indian publicly traded corporates, categorized as local private, foreign and government owned firms; second, whether endogenously determined cut-off points/nodes of busyness, incorporating firm ownership characteristics, provide better insights when compared with the exogenous limits of busyness mandated by the regulator in India; and lastly, whether the nature of busyness also affect the financial reporting quality along with the number of it.

The current study derives its theoretical foundations from the agency, and resource dependence theories. An argument following from the agency theory is that an increased busyness level of the audit committee members of a firm on boards and committees of other firms can create paucity of time and focus, which are necessary ingredients to perform highly specialized tasks related to the audit committee, including ensuring objectivity and truthfulness of financial statements; and consequently financial reporting quality may deteriorate (Ferris et al., 2003; Sharma and Iselin, 2012). An alternative argument following from the resource dependence theory is that the multiple directorships of audit committee members of a firm underscores their high levels of reputational capital, which these directors acquire through their human capital and relational capital. Therefore, it may be argued that when busy directors join the audit committee of the firm, then such directors, due to the amount and diversity of their accumulated experience, skills, knowledge, among other things, can understand financial health of the firm and effectively monitor managerial actions and resultantly the quality of financial reports can increase (Pfeffer and Salancik, 1978; Hunton and Rose, 2008; He and Yang, 2014). Major contributors to the human capital are education, experience, skills, training and expertise of directors; whereas those to the relational capital are network of ties with other organizations and external contingencies accumulated over time (Hillman and Dalziel, 2003). In the current paper, the human capital and the relational capital put together is termed as the reputational capital of directors.

In the post-Sarbanes-Oxley (SOX) environment, there has been a significant increase in corporate governance responsibilities and liabilities of boards of directors in many countries including India (MCA, 2013). Similarly, there has been a significant increase in the responsibilities of audit committee members, particularly in the context of oversight of financial reporting process, monitoring of managerial actions, internal audit and control system, auditors' selection and rotation, transparency regarding audit and non-audit services (NAS) fees, auditors' independence, and performance evaluation and issues related to whistle-blowers (Sharma and Iselin, 2012). At the same time, the amount of scrutiny and monitoring that the audit committees invite from regulators, analysts, institutional investors, and other capital market participants have also increased unprecedentedly (Sharma and Iselin, 2012). The section 177 of the Companies 
Act of India (MCA, 2013) has expanded the scope of responsibilities of the audit committees in India, and currently an audit committee is also required to give its recommendations on the matters related to appointment of auditors and monitor their independence and performance, approve related party transactions, and scrutinize inter-corporate borrowings and investments.

According to the clause 292A of the Indian Companies Act of 1956 (MCA, 1956), a public company having a paid-up capital not less than fifty million rupees must have an audit committee comprised of at least three directors and two-thirds of its directors to be nonexecutive. The Section 275 of the above law also required limiting maximum number of directorships in the publicly traded firms to fifteen, which was later increased to twenty. Nevertheless, there were many ambiguities, and exceptions in the law and directors could easily exceed their number of directorships over twenty (Hundal, 2013). The Securities and Exchange Board of India (SEBI), the principal financial regulator of India, recognized in the clause 49 of the listing agreement between a firm and a stock exchange in India that in order to improve quality of financial reporting, it was important to enhance the independence of the audit committees by changing their composition (SEBI, 2000). The clause 49 required an audit committee to have a minimum size of three and comprised exclusively of non-executive directors with majority of them must be independent directors. However, the revised clause 49 excluded the requirement of the non-executive directors and instead stipulated that the audit committee must have a minimum of three members with two-thirds of them to be independent directors (SEBI, 2004). A significant regulatory development witnessed in year 2013 has been the approval of the Companies Act of India by the Indian parliament, and now this new law requires an audit committee to have a minimum of three directors with independent directors forming a majority. Furthermore, the Companies Act 2013 removed the requirement of the independent director to chair the audit committees. An insight appears from the above mentioned regulatory developments that several revisions have actually paved the way for executive directors to become chairs and members of audit committees in India. In promoter dominated corporate settings, such developments can put even more pressure on the independent functioning of audit committees. Regarding the multiple directorships, the section 165(1) of this newly introduced regulation states that, "No person, after the commencement of this Act, shall hold office as a director, including any alternate directorship, in more than twenty companies at the same time: Provided that the maximum number of public companies in which a person can be appointed as a director shall not exceed ten" (MCA, (2013), 97).

In the current paper I have applied the spline regression technique (see Ahlberg et al., 1967; De Boor, 2001) in the empirical analysis in order to endogenously determine cut-off points of multiple directorships from three to ten. Sarkar and Sarkar (2012) argue that since three directorships is the recommended number of outside directorships in the US, many empirical studies even in the non-US settings have also taken three directorships as a measure of busyness. This is a major limitation observed in the extant literature. The range of busyness in the current paper ends at ten, as this is the maximum number of directorships that a corporate director can take up according to the section 165(1) of the Companies Act of India (MCA, 2013). In order to recognize differences in corporate institutional settings among firms based on their ownership structure, the full sample is categorized into three sub-samples, that is local private, foreign and government firms. It is noticeable that after the economic policy of liberalization was initiated in 1991, Indian corporate sector has witnessed remarkable expansion of the private sector, which can be further categorized as local private and foreign firms, however, at the same time the 
government sector is still maintaining its traditional dominance (Sarkar and Sarkar 2012). This is the reason for doing empirical analysis by taking three sub-samples as well as full sample, as the phenomenon of busyness can affect different firms differently.

For the sub-samples and full sample, the busyness of audit committee members adversely affects the financial reporting quality at a lower level of busyness, although at different cut-off points, than those specified by regulator. Similarly, the foreign, local private sector firms, and the full sample firms experience improvements in the financial reporting quality only at the lower level of busyness. The intensity of busyness affects the financial reporting quality of the government, local private firms and full sample unfavorably at a relatively higher level of audit committee members' busyness, whereas, the favorable effects occur only to the foreign firms, albeit, at a lower level of busyness.

The current paper makes several contributions to the extant literature, first, the endogenously determined busyness limits explain the association between the multiple directorships of audit committee members and the quality of financial reporting better than those exogenously prescribed by regulators; second, despite applying the endogenous limits of busyness in the analysis for the full sample and sub-samples, the results reveal that 'one size does not fit all', that is the cut-off points of busyness, highlighting the optimum level of busyness for the different ownership groups, are not uniform across sub-samples; third, along with the number of multiple directorships of the audit committee members, the nature of multiple directorships also affects the financial reporting quality; and lastly, the current paper is one of the few studies in the settings of an emerging economy, such as India, and the findings of this paper can be useful for countries having comparable corporate landscape.

The remainder of the paper is divided into the following sections: prior literature and hypotheses development, research design, empirical findings and discussion and conclusions, and future research.

\section{Prior Literature and Hypotheses Development}

After witnessing a series of corporate failures, notably Enron, at the beginning of the 21st century, the Securities and Exchange Commission (SEC, 2002) of the USA placed additional emphasis on revamping internal corporate governance system, particularly audit committees, in order to improve quality of financial reporting, and increase accountability of firm decision makers. Even before corporate failures, the Blue Ribbon Committee (BRC) advocated making the audit committees more effective and powerful, in order to ensure that firm managements would adopt and follow a sound system of internal controls and procedures, assess managerial actions objectively through various reviews, and disclosures and make truthful assessment of financial reports (BRC, 1999).

The audit committee is one of the various internal corporate governance mechanisms, and its principal objective is to ensure that the financial statements and disclosures are prepared according to the legal requirements and accounting standards, in order to portray a comprehensive and true picture of the financial health of the firm (Sarens and Abdolmohammadi, 2011). The audit committee ensures fairness of financial information, and promotes a culture of accountability within the organizational structure of firms (BRC, 1999). The audit committee "...helps to ensure that management properly develops and adheres to a sound system of internal 
controls, that procedures are in place to objectively assess management's practices and internal controls, and that the outside auditors, through their own review, objectively assess the company's financial reporting practices" (Standards Relating to Listed Company Audit Committees, (2003), 69).

The audit committee interacts with the external auditors and firm managements in order to perform its core functions. To overcome any possible collisions between the two, the audit committee ensures that the firm managers provide all the relevant documents and other information to external auditors in order to check the authenticity of financial data. Similarly, to avoid any possible collusions between the external auditors and the firm managers, the audit committee recommends the scope of the auditing services, the amount of audit fees and the NAS engagements between the firm and external auditors (Antle, 1982; Sarkar and Sarkar, 2012). Antle (1982) argues that collusions between the firm managers and the external auditors can lead to another dimension of the agency theory called two-agent model, whereby, an agent (manager) hires another agent (external auditor), theoretically, to enhance the credibility of information, however, in reality, both agents are able to collude in order to enhance and protect their personal interests, and therefore, inflict the agency costs on the firm. The verification done by the external auditors provides legitimacy to the financial information provided by the firm managers; however, the independence of implementation of this process can be questioned due to managerial interventions and business interests of mangers and auditors.

The audit committee can perform its functions efficiently, when it is able to operate independent of managerial influences (DeZoort et al., 2002). According to the BRC, "Members of the audit committee shall be considered independent if they have no relationship to the corporation that may interfere with the exercise of their independence from management and the corporation" (BRC, (1999), 10). The SOX (2002) mandates an audit committee to be exclusively comprised of independent directors, and it directs the national securities exchanges and the national securities associations to prohibit the listing of firms that do not comply with the audit committee requirements of independence.

An important determinant of the independence of the audit committee of a firm is the number of directorships (boards and committees) taken up by its members in other firms. It can be postulated from the agency theory (Jensen and Meckling, 1976) that a firm by inducting independent directors on an audit committee can ensure objectivity, truthfulness and fairness of its financial reports. Nonetheless, as the number of outside directorships of the audit committee members of a firm increases, their effectiveness to review financial statements may diminish and as a result quality of the financial data may deteriorate (Sharma and Iselin, 2012; Ferris et al., 2003). The busyness of the audit committee members can adversely affect quality of financial reporting in two ways. First, busy audit committee members may not have enough time to verify truthfulness and fairness of financial reports. There is no denying the fact that specialized skills, knowledge, and experiences of audit committee members are important determinants of the quality of financial reporting, however, such virtues can be of little value if the audit committee members become overcommitted by taking up multiple directorships and as a result do not have sufficient time to effectively monitor, and oversight financial reporting process (Jiraporn et al., 2009; Ahn et al., 2010). Tanyi and Smith (2015) oppose additional directorships accepted by the audit committee members of a firm, because in the post-SOX scenario the responsibilities of audit committee members have substantially increased, therefore, additional directorships can 
inhibit the audit committee members to perform their stipulated responsibilities. To supplement their argument, Tanyi and Smith (2015) provide evidence that the average number of times an audit committee holds its meetings in a year has increased from 3.2 in 1998 to 8.2 in 2004 (Linck et al., 2009) and audit committee's per meeting duration that used to be ninety minutes in the pre-SOX period has risen to five hours in the post-SOX era (Beasley et al., 2009).

Second, when monitoring the financial reporting process, the busy audit committee members may not pay attention to certain strategic aspects and such omissions can be harmful to the firm. Financial reporting is not an end in itself, as it plays important roles in the formulation, implementation, reviews, and revisions of corporate policy, planning, and strategies and decision making, among other things. Generally, the process of receiving and processing information, followed by actions based thereon pertaining to a given task, restricts the similar process with respect to other tasks due to scarcity of attention (Kahneman, 1973; Eysenck and Keane, 1990; Fiske, 1995). Similarly, it can be posited from the above statement that when the audit committee members of a firm are serving on boards of other firms, they may experience lack of attention, and as a result they neither have in-depth understanding of financial reports nor draw inferences about the interplay between the key financial characteristics/results and other aspects of firms. Due to lack of attention of audit committee members, not only quality of financial reports is compromised but even further, such reports lose their utility in the corporate policy, planning and decision making. Tanyi and Smith (2015) find that the financial reporting quality of firms deteriorates when their audit committee chairpersons and financial expert members are busy. Above finding underlines that busy experts of audit committees may find it difficult to focus on their key tasks and as a result the financial reporting quality declines. Similarly, based on the analysis of a large sample of Australian firms, Méndez et al. (2015) find that increased busyness of the audit committee members of a firm limits their capacity to monitor managerial actions, and effectiveness to implement internal control mechanisms, which lowers the quality of financial reports. The above study further finds that busyness of directors at the overall board level is associated with disproportionately higher CEO remuneration, and lower payperformance sensitivity.

He and Rong (2014) give empirical evidence that the audit committee members in regulated firms have fewer directorships in other firms in comparison to their counterparts in unregulated firms. Following reasons can be postulated why audit committee members in regulated firms have fewer directorships in other firms, first, regulated firms are larger in size, and more complex business organizations, therefore, the audit committee members do not have much time and other resources to take up additional directorships in other firms beyond a certain level, and second, the audit committee members of regulated firms, generally, have longer tenure of affiliation due to certain firm specific characteristics of regulated firms. The audit committee members invest relatively more time and efforts in understanding the complexity and other dynamics of the regulated firms, and these firms find it difficult to find replacement of such members, who become privy to several firm specific characteristics. He and Rong (2014) provide empirical support to above arguments as they find lower level of earnings management practices at the lower level of the busyness of audit committee members in regulated industries.

A counter argument to the above follows that despite serving on multiple firm boards and committees, the audit committee members can still ensure the quality of financial reporting, because firms that appoint them in the audit committee can also provide them with the 
subordinate staff, and other related services so that the audit committee can still perform its core tasks efficiently; nonetheless, too busy audit committee directors can find it difficult to coordinate their multiple tasks, and crosscheck whether accountants have followed compliance with respect to the accounting standards, and legal requirements. The potential loss of reputation and litigation risks can act as deterrents to the audit committee members of a firm from taking too many directorships in other firms (Skinner and Srinavasan, 2012).

In a country like India, promoters including individuals and firms, occupy a pivotal place with respect to the ownership, and control structure of firms (Sarkar and Sarkar, 2012; Khanna and Mathew, 2010). Based on the study of Hermalin and Weisbach (1998), it can be argued that in a corporate ownership structure, which is dominated by business groups, similar to that of India, the powerful CEOs may handpick and appoint those audit committee members of the firm on boards of other group-affiliated firms, who are, generally, loyal to them and poor monitors, in order to consolidate their position. Such phenomenon, known as interlocking, gathers even more relevance in a country like India, where a director can join as many as ten boards of directors of listed companies (MCA, 2013). It can be posited from the agency theory that if promoters follow the above mentioned maneuver of interlocking, then a likely by-product may emerge in the form of lower monitoring of managerial actions and consequently lower quality of the financial reports. Furthermore, the phenomenon of 'extended interlocking' can also be observed with the auditor joining the trio including promoters, executives and audit committee members of the firm. In this arrangement of extended interlocking, the promoters, who have substantial control over firm executives, may appoint their favorite audit committee members on the multiple firms in the business group, and their social ties gets further fillip with the inclusion of auditors of their choice. Johansen and Pettersson (2013) find that in the interlocked relationship audit committee members and promotors generally employ the same audit firm in the business group firms. The increasing familiarity between the participants of the extended interlocking can result in lesser monitoring of managerial actions and diminishing credibility of audit quality, which can result in lower financial reporting quality.

In several countries, regulatory provisions, such as Section 177(4) of the Companies Act of India 2013, provides for explicit approval of audit committees in the matters pertaining to appointment, reappointment, and remuneration of external auditors (MCA, 2013). Such economic dependence of audit firms is capable of bringing them closer to the audit committees, who are assumed to be already in the influence of the promoters. Furthermore, an audit committee is also supposed to monitor auditor performance, and give its approval before the public release of financial statements of the firm. Nonetheless, based on some studies (e.g., Chen et al., 2014), it can be expected that in an extended interlocking system, the level of diligence, and oversight applied by the audit committees, in order to check the auditor performance, may be weaker. In several empirical studies, including that of Zang and Emanueal (2008), the proportion of the non-audit revenue to total revenue earned by the auditor from a client firm is used as a measure of extended interlocking. Based on the above discussion following hypothesis is tested:

$H_{1}$ : Multiple directorships of the audit committee members unfavorably affect quality of information (agency theory). 
However, according to an alternative argument, backed by the resource-dependence theory, directors of a firm can perform their core responsibilities efficiently if they have a high quality of human capital (experience, expertise, skills) and relational capital (network of ties to other firms, external environment and external contingencies) of such members (Pfeffer and Salancik, 1978; Pearce and Zahra, 1992; Hillman and Dalziel, 2003). In the current paper, I have named the sum of the human capital and the relational capital as the reputational capital. In particular, the audit committee functions require specialized skills, experience, and expertise, and also interactions with the external environment; therefore, it can be maintained that the phenomenon of busyness can provide a platform to audit committee members whereby they can update and enhance their reputational capital. Fama and Jensen (1983) hold that similar to that of firms; reputation carried by directors in the labor market of corporate directors is highly significant. Accordingly, it can be argued that among other determinants the phenomenon of multiple directorships facilitates the audit committee members to enhance their reputational capital in the market of corporate directors. Several studies provide empirical support for the claim that the audit committee members, serving on multiple boards, experience increase in their reputation (Vafeas, 1999, 2001; Perry and Peyer, 2005).

Vafeas (1999) considers multiple directorships as a proxy for the reputational capital of board/committee directors, which is earned and accumulated over a period of time; therefore, such directors have the fear of losing their reputational capital due to regulatory actions, and adverse market reactions in the event of their negligent behavior, and poor performance (Watts and Zimmerman, 1983; Ball, 2009). For example, when a regulator identifies some errors and accounting standards violations, and asks the firm to make necessary rectifications in the financial statements issued by it, then the audit committee members of such firm are not only highly likely to relinquish their audit committee seat in the firm but are also less likely to receive invitations to join boards and committees of other firms. Similarly, it can be inferred, based on the findings of Helland (2006), that the labor market of corporate directors rewards those audit committee members with additional directorships, who detect/prevent financial frauds.

It is further reasoned that in order to perform their roles and responsibilities objectively nonexecutive board members, in general, and audit committee members, in particular, are not expected to collude with the firm management. For audit committee members, in order to play their role in ensuring fairness and truthfulness of the financial reporting process, it is very important to have the attitude of skepticism. It is conjectured that when audit committee members of a firm have directorships in other firms, they have less dependence (for example, meeting fees) on a particular firm, therefore, busy audit committee members are more likely to maintain arm's length distance from the firm executives and enhance their reputation (Kaplan and Reishus, 1990). The audit committee members, holding multiple directorships, are relatively more concerned of the potential litigation risk, and erosion of their reputation in the event of detection of financial errors/frauds. Such high stakes are capable of bringing the behavioral aspects of audit committee members in the forefront, as they may self-impose a system of compliance, skepticism, diligence and monitoring, which may be even more stringent than the statutory requirements, in order to ensure that financial statements are true, objective and unbiased (Sharma and Iselin, 2012; Skinner and Srinavasan, 2012). Sharma and Iselin (2012) further posit that some audit committee directors, owing to their higher reputation capital, symbolized by multiple directorships, can be relatively upfront in demanding the required information and unobstructed communication with external auditors, and other components of 
internal corporate governance system, from the firm management. Therefore, multiple directorships may enhance effectiveness of the audit committee, resulting in increased informativeness of financial data. He and Rong (2014) find that for firms functioning in unregulated industries, there is an inverse relationship between additional directorships of their audit committee members and earnings management practices.

It is further argued that since regulators and professional bodies require the audit committee members to have specialized qualifications, experience, and expertise, therefore, such requirements make them 'scarce resources'. Sarkar and Sarkar (2012) have highlighted that the phenomenon of busyness of audit committee members can be a solution to the problem of scarcity of managerial talent. Similarly, it can also be posited from the resource dependence theory that the interlocking mechanism used by a firm's promoters can bring various benefits to it. By appointing the audit committee members of a firm on other boards within a business group, promoters can make efficient utilization of their managerial resources and thus offset the deficiency of managerial talent, which is a big limiting factor in a country like India (Sarkar and Sarkar 2012).

Similar arguments can also hold true for the extended interlocking arrangement. It may be possible that firm auditors and promoters develop difference of opinion, for example, on the matters pertaining to the financial reporting compliance; however, in such situation the audit committee can mediate between them and diffuse any potential conflict (Chen et al., 2014; DeZoort et al., 2003). Similarly, due to their finance and accounting background, both education and professional, first, the audit committee members of a firm can be more effective in helping auditors to develop understanding regarding various firm specific characters, and second, auditors can explain their audit policy to the audit committee members in a more meaningful manner. Such cooperation between the audit committee members, and auditors may result in the latter experiencing lesser pressure to perform their core responsibilities and also building trust between the auditors and the firm. The following hypothesis, based on the favorable effects of the busyness of audit committee members, is tested.

$\mathrm{H}_{2}$ : Multiple directorships of the audit committee members favorably affect quality of information (resource dependence theory).

When studying the association between the multiple directorships of the audit committee members and the financial reporting quality, it is also important to consider the nature of busyness along with its number. The amount and complexity of workload is relatively higher when corporate directors are members of specialized committees, for example, audit, committee and compensation committee. Ferris et al. (2003) highlight that higher compensation can motivate directors to accept committee memberships in other firms, and such directors may find it difficult to perform the tasks entrusted to them. Tanyi and Smith (2015) and Méndez et al. (2015) also show similar findings.

$H_{3}$ : High intensity of busyness unfavorably affects the quality of financial reporting.

It is important to study the association between busyness of audit committee members and financial reporting quality in the light of ownership structure of firms. The equilibrium level of 
busyness depends on multiple firm-specific characteristics, requirements, and objectives, therefore, the limits to audit committee members' busyness should be determined endogenously (Demsetz and Lehn, 1985). Several other studies (e.g. Hermalin and Weisbach, 2003; Tanyi and Smith, 2015) find empirical evidence to support the above argument that the optimum board/committee structure is endogenously determined as it is sensitive to institutional settings of the firm and prescribed exogenous limits by the regulator are less effective in enhancing financial reporting quality.

\section{Research design}

\subsection{Sample size and data}

The analysis of the current paper is based on a final sample of an unbalanced panel of 3733 firmyears of non-financial publicly traded companies listed on the Bombay Stock Exchange (BSE) and National Stock Exchange (NSE) over the period of 2004-12. The full sample of 3733 firmyears is further divided into sub-samples of firms categorized on the basis of their ownership including 2376 local Indian private, 772 government and 585 foreign ${ }^{1}$ firm-years. The initial dataset contained 5386 firm-years, however, 701, 505, and 447 firm-years observations pertaining to Indian private, government, and foreign firms, respectively, were lost due to nonavailability of the data. The major unavailable data in the corporate governance reports were details about busyness of audit committee directors (628 firm-years), and financial expertise (242 firm-years) of the chairperson of audit committees. Similarly, in the financial statements, major omissions of the data were pertaining to expenditure on the NAS (272 firm-years), research and development (234 firm-years), and advertisement (277 firm-years).

The data have been obtained from Prowess database, a proprietary of the Center for Monitoring the Indian economy (CMIE). In addition to the data obtained from Prowess, information on accounting indicators, equity ownership, stock market variables, and other firm characteristics for analysis, have been obtained from, annual reports of firms, particularly financial statements and corporate governance reports, the SEBI, the BSE and the NSE.

\subsection{Empirical methodology and constructs}

The definitions, and measurement issues related to explained, and explanatory variables are discussed below-

\subsubsection{Performance variables}

Earnings management practices, carried out by a firm, determine its quality of accounting information. In this paper, I have used discretionary accruals as a proxy of the magnitude of earnings management, hence, quality of accounting information. Discretionary accruals are obtained by subtracting non-discretionary accruals from total accruals. Non-discretionary accruals are estimated by using a regression model that regress total accruals on several explanatory variables.

\footnotetext{
${ }^{1}$ Foreign firms also include those established by the Non-resident Indians (NRIs).
} 
In the current paper, I have used discretionary accruals as a measure of earnings management (Bedard et al., 2004).

Discretionary accruals are measured by applying model given by Jones (1991).

$\mathrm{DA}_{\mathrm{it}}=\mathrm{TA} \mathrm{A}_{\mathrm{it}} / \mathrm{A}_{\mathrm{it}-1}-\left[\alpha_{1}\left(1 / \mathrm{A}_{\mathrm{it}-1}+\alpha_{2}\left(\Delta \mathrm{REV}_{\mathrm{it}} / \mathrm{A}_{\mathrm{it}-1}\right)+\alpha_{3}\left(\mathrm{PPE}_{\mathrm{i}} / \mathrm{A}_{\mathrm{it}-1}\right)+\varepsilon_{\mathrm{it}}\right]\right.$

DA $_{i t}=$ Discretionary accruals of $i^{\text {th }}$ firm in $t^{\text {th }}$ (current) period

$\mathrm{TA}_{\mathrm{it}} \quad=$ Total accruals of $\mathrm{i}^{\text {th }}$ firm in $\mathrm{t}^{\text {th }}$ (current) period. Total accruals are measured by subtracting cash flows from operations from net income before extraordinary items

$\mathrm{A}_{\mathrm{it}-1} \quad=$ Assets of $\mathrm{i}^{\text {th }}$ firm in $(\mathrm{t}-1)^{\text {th }}$ (previous) period

$\triangle \mathrm{REV}_{\mathrm{it}} \quad=$ Change in net sales of $\mathrm{i}^{\text {th }}$ firm in $\mathrm{t}^{\text {th }}$ (current) period

$\mathrm{PPE}_{\mathrm{it}} \quad=$ Gross value of Property, plant and equipment of $\mathrm{i}^{\text {th }}$ firm in $\mathrm{t}^{\text {th }}$ (current) period

$\varepsilon_{i t} \quad=$ Error term

Jones' (1991) expectation model is used to measure non-discretionary accruals as below:

$\mathrm{TA}_{\mathrm{it}} / \mathrm{A}_{\mathrm{it}-1}=\alpha_{1}\left(1 / \mathrm{A}_{\mathrm{it}-1}\right)+\alpha_{2}\left(\Delta \mathrm{REV}_{\mathrm{it}} / \mathrm{A}_{\mathrm{it}-1}\right)+\alpha_{3}\left(\mathrm{PPE}_{\mathrm{it}} / \mathrm{A}_{\mathrm{it}-1}\right)+\varepsilon_{\mathrm{it}}$

The term $\left[\alpha_{1}\left(1 / \mathrm{A}_{\mathrm{it}-1}+\alpha_{2}\left(\Delta \mathrm{REV}_{\mathrm{it}} / \mathrm{A}_{\mathrm{it}-1}\right)+\alpha_{3}\left(\mathrm{PPE}_{\mathrm{it}} / \mathrm{A}_{\mathrm{it}-1}\right)\right]\right.$ represents the estimated value of the term $\mathrm{TA}_{\mathrm{it}} / \mathrm{A}_{\mathrm{it}-1}$. Jones (1991) argues that the terms $\mathrm{PPE}_{\mathrm{it}}$ and $\Delta \mathrm{REV}_{\mathrm{it}}$ signify changes in nondiscretionary accruals caused by changing economic environment. Change in revenue affects change in working capital, which, in turn affects TA. Revenue is exogenous as it reflects economic realities; therefore, one may argue that revenue is an objective measure of corporate performance. Nonetheless, according to an alternative argument revenue can be endogenous too, for example managers have strong motivation to overstate/understate revenue in accordance to their own utility function (Marciukaityte and Szewczyk, 2011).

The term PPE $\mathrm{it}_{\mathrm{it}}$ in the expectations model controls for the proportion of total accruals arising due to nondiscretionary depreciation expense. The rationale for using gross value of property, plant, and equipment instead of change in it is that total depreciation expense is included in the total accruals measure. Similarly, all terms in the accruals expectations model are scaled by lagged assets in order to lessen heteroscedasticity (Jones, 1991). The difference between actual and estimated values of $\mathrm{TA}_{\mathrm{it}} / \mathrm{A}_{\mathrm{it}-1}$ denotes discretionary accruals.

Total accruals are calculated as the change in non-cash working capital before income tax payable less total depreciation expenses. Jones (1991) provides a formula of deriving total accruals as below:

$\mathrm{TA}_{\mathrm{t}}=\left[\Delta\right.$ Current Assets $\left._{\mathrm{t}}-\Delta \mathrm{Cash}_{\mathrm{t}}\right]-\left[\Delta\right.$ Current Liabilities $_{\mathrm{t}}-\Delta$ Current Maturities of Long-Term $^{-}$ Debt $_{t}$ - $\Delta$ income Taxes Payable $_{t}-$ Depreciation and Amortization Expense $_{t}$. The change $(\Delta)$ is computed between time periods $\mathrm{t}$ and $\mathrm{t}-1$.

Jones (1991) highlights that estimated TA as given in the expectation model represents normal accruals, therefore, the total amount of accruals has been taken in the model as against change in total accruals. 


\subsubsection{Busyness variables}

Following three busyness variables are below:

1. Spline 1 Directorships (Spline-1),

2. Spline 2 Directorships (Spline-2),

3. Median Committee to Board Size (Comm-BS)

The spline regression technique overcomes the limitation of using an exogenously determined cut-off point of busyness. In this technique, changes in the slope at two pre-determined specific points, known as spline knots/nodes/cut-off points, are endogenously determined (Ahlberg et al., 1967).

Busyness is measured as the audit committee level median of total directorships (board plus committees); hereafter referred as median directorships, showing the number of outside directorships held by majority i.e. fifty percent of the audit committee. Spline nodes range between three to ten directorships taken up by directors. The range starts with 'three' directorships as majority of empirical studies in the US, and even in non-US settings, take three directorships as a measure of busyness. The range ends with ten as this is the maximum number of directorships that a corporate director can take up according to the section 165(1) of the Companies Act of India (MCA, 2013). Also, the Act does not distinguish between board and committee memberships.

The spline coefficients are calculated as suppose the financial reporting quality (dependent variable) is a function of busyness (independent variable), then ' $x$ ' is the observed audit committee level median directorship and the above mentioned functional relation is estimated at different endogenous spline knots/nodes/cut-off points. The Spline-1 and the Spline-2 can be defined as below:

Spline- $1=\mathrm{x}$, if $\mathrm{x}<\mathrm{x}_{1}$

$=x_{1}$, if $x \geq x_{1}$

Spline-2 $=0$, if $x<x_{1}$

$$
=\left(x-x_{1}\right) \text {, if } x \geq x_{1}
$$

1. Spline-1- This coefficient of the Spline- 1 variable at $j^{\text {th }}$ ( $j$ varies from 3 to 10 ) node/limit shows the effect of audit committee level median directorships ( $\mathrm{x}$ ) below a given node/limit $\left(\mathrm{x}_{1}\right)$ on the discretionary accruals. A positive coefficient implies that when the audit committee level median directorships are even less than a given endogenous node/limit, the busyness of directors at the given level is associated with increasing discretionary accruals, signifying decline in the quality of accounting information. Here, the underlying assumption is that busyness of directors of an audit committee beyond a certain limit can inflict agency costs on the firm.

2. Spline-2- This coefficient of the Spline-2 variable at $j^{\text {th }}$ ( $j$ varies from 3 to 10 ) node/limit shows the effect of audit committee level median directorships ( $\mathrm{x}$ ) at and above a given node/limit $\left(\mathrm{x}_{1}\right)$ on the discretionary accruals. A negative coefficient implies that when audit committee level median directorships exceed a given node/limit, the discretionary accruals diminish, and the quality of accounting information improves. Here, the underlying assumption 
is that the busyness of directors of an audit committee beyond a certain limit can actually improve the quality of information due to their enhanced reputational capital.

3. Median committee to board size (Median committee-board size)- This is a measure of the intensity of busyness. It may be posited that when an audit committee member of a firm serves on specialized committees, such as audit committee, remuneration committee, and nomination committee, of other firms then it is expected that the audit committee member will find his/her workload more than when he/she accepts the same number of positions on the general board of directors. The findings of Tanyi and Smith (2015) and Méndez et al. (2015) provide empirical support to the above argument. This firm level measure is equal to the median committee directorships undertaken by the audit committee members of a firm, scaled by the board size. The expected sign of the coefficient of this variable can be negative (resource dependence argument) or positive (agency theory argument).

\subsubsection{Corporate governance variables}

The following corporate governance variables are included in this paper:

1. Board size- Dalton et al. (1999) and Goilden and Zajac (2001) highlight that board size affects firm performance favorably. The larger boards are more likely to have more and diverse reputational capital, and experience effective monitoring and control, which may result in higher quality of financial reporting process. On the other hand, Jermias and Gani (2014) and Guest (2009) find that it is relatively easier for the CEOs of firms having larger boards to influence outside directors and win their loyalty. Therefore, it can be assumed that firms with larger boards have lower quality of financial reporting. In the current study log values of board size are taken in order to avoid linearity, and no sign of the coefficient of the board size is predicted.

2. Independent directors proportion- The independent directors of a firm have a strong motivation to monitor the firm management in order to enhance their reputational capital in the labor market of corporate directors. 'Like board, like committees', implies that if a board of directors is relatively independent then it is more likely to induct independent directors in the committees too. Donnelly and Mulcahy (2008) find that an independent board itself plays an important role in reducing the information asymmetries between owners and managers. It is predicted that such board through its actions, and cooperation with the audit committee, can improve the quality of financial reports. This variable is calculated as the ratio of the number of independent directors to the board size of a firm. The squared values are taken in order to minimize the linearity problem, and the predicted sign is negative.

3. Audit committee chairperson financial expertise (AC chair expertise)- The role of the chairperson of an audit committee is highly demanding. In the post-SOX scenario this role has increased manifolds. One of the most important objectives of an audit committee is to ensure that financial reporting quality and internal risk management is of the highest order, and in order to achieve this objective efficiently the chairperson of an audit committee is required to spend a large amount of time and attention. Tanyi and Smith (2015) underscore that the workload of an audit committee chairperson is substantially higher than an ordinary member of the same 
committee. The SOX Act (2002) requires that a firm must disclose in SEC filings that its audit committee chairperson and other committee members fulfil the education criteria in the field of finance. Several studies give empirical evidence that an audit committee chairperson, who has education in the field of finance and accounting, can perform such a challenging job in a more efficient manner. Abbott et al. (2004) and Bedard et al. 2004) find that firms having audit committees chaired by financial experts, experience less earnings management, and accounting restatements. In the current paper, this variable is a binary with the value ' 1 ', if the chairperson of the audit committee has financial/accounting qualification, ' 0 ' otherwise. The predicted sign of this variable is negative.

4. Debt-equity ratio- The principal-agent problem also exists between debt holders and management (Jensen and Meckling, 1976). Sarkar and Sarkar (2012) hold that in India debt plays an important place in the capital structure of firms. Therefore, a firm board in order to have cordial relationship with its debt holders, especially banks, can strengthen its internal control system, particularly by inducting more independent members in the audit committee. An independent audit can play an important role in increasing the reliability of the accounting numbers and mitigating monitoring costs of debt holders, therefore, the firm can obtain more debt at competitive terms (Sarens and Abdolmohammadi, 2011). Therefore, a negative association can be predicted between leverage and discretionary accruals. In the current paper, leverage is measured as a ratio of total value of debt to total market value of outstanding equity capital.

5. Ratio of NAS revenue to total revenue of auditor- The current paper takes this ratio as the measure of extended interlocking. The section 139 of the Companies Act of India (MCA, 2013) disallows auditors to perform several types of NAS for their client firms (also subsidiaries and holding companies), including accounting and book keeping, investment advisory/banking, and internal audit services. However, there are several other types of services that audit firms can still do for their client firms. In the extended interlocking relationship, the audit committee members, and promotors often employ the same auditor in various firms in the business group (Johansen and Pettersson, 2013). The audit committees, executive directors and promoters of the client firms may prefer their audit firms to do the NAS too. However, a rising ratio of the NAS revenue to the total revenue of an auditor earned from a given client firm may also underpin diminishing independence of audit committee, weaker monitoring and control of managerial actions and lower quality of financial reports (Simunic, 1984; Beck et al., 1988). Zang and Emanueal (2008) find that when the relative share of NAS revenue to total revenue that an auditor earns from the client firm increases, it may imply that economic interests of an auditor are highly ingrained in the firm, and resultantly the auditor is less likely to challenge earnings management actions of managers. The predicted sign of this variable on firm performance is positive.

\subsubsection{Firm Level Control Variables}

In order to control for firm specific characteristics, the following variables have been added to the model: 
1. Research and development (R\&D) intensity and 2. Advertisement intensity- Among control variables, research and development intensity and advertisement intensity are calculated by dividing respective expenditure on both items by sales revenue. These two variables are measures of firm growth as well bonding costs of managers (Ang et al., 2000; Easterbrook, 1984). Bonding costs are a part of agency costs, and are costs incurred by the agent in order to reflect his commitment to the firm. Such costs may also be incurred in order to give positive signals to investors and expect positive reaction of stock market (Jensen and Meckling, 1976). The predicted sign of both variables is negative.

3. Trade intensity- Trade intensity shows how actively equity shares of a firm are traded in the stock market. This variable is calculated by dividing the number of shares traded by the total number of shares outstanding. Firms having active stocks are less likely to do earnings management as such action can invite stock market ire (Fan and Wong, 2002). The predicted sign is negative.

4. Market-capitalization- Firm size is measured by market-capitalization (log values). Marketcapitalization is obtained by multiplying the market value of a share by the number of shares outstanding, at the end of the year. Big sized firms are less likely to use earnings management practice due to potential loss of reputation (Carey and Simnett, 2006). The predicted sign is negative.

The ordinary least square (OLS) regression technique is used to estimate the following functional relationship of the model:

DA $_{i t}=\alpha_{i t}+\beta_{1}(\text { Spline- } 1)_{j}^{2}+\beta_{2}(\text { Spline- } 2)_{j}+\beta_{3}(\text { Median committee-board size })_{i t}+\beta_{4}(\text { Board size })_{i t}$ $+\beta_{5}(\text { Independent directors proportion })_{\mathrm{it}}+\beta_{6}(\mathrm{AC} \text { chair expertise })_{\mathrm{it}}+\beta_{7}(\mathrm{R} \& \mathrm{D} \text { intensity })_{\mathrm{it}}+$ $\beta_{8}(\text { Advertisement intensity) })_{\mathrm{it}}+\beta_{9}\left(\right.$ Trade intensity) ${ }_{\mathrm{it}}+\beta_{10}(\text { Debt-Equity ratio })_{\mathrm{it}}+\beta_{11}$ (Marketcapitalization $)_{i t}+\beta_{12}(\text { NAS to total revenue of auditor })_{i t}+$ error term

\section{Empirical findings and discussion}

From table 1 it can be noticed that the predicted sign of $\alpha_{2}$ is positive, because the working capital is expected to increase with the increase in the sales revenue. Similarly, the predicted sign of $\alpha_{3}$ is negative; because a higher amount of fixed assets produces higher depreciation expenses and deferred taxes, and as a result total accruals, measured by subtracting cash flows from operations from earnings before extraordinary items, decrease (Klein, 2002). From table 1, it can be seen that the expected and the realized coefficients have same signs. Nonetheless, $\alpha_{2}$ and $\alpha_{3}$ are significant for the full sample and sub samples, except for the sub sample of government owned firms. This finding indicates that the local private and foreign firms, in India, have the tendency to inflate (deflate) their income by increasing their sales revenue (expenditure on fixed assets). Based on the findings, given in table 1, it can be interpreted that the incidence of earnings management, measured by the discretionary accruals, has been relatively prominent in

\footnotetext{
${ }^{2}$ Spline-1 and spline-2 variables represent firm-level busyness nodes from three to ten.
} 
the local private and foreign firms in India. There has been no prediction made about the sign of $\alpha_{1}$, however, the same has been found to be negative for the local private sector firms, and positive for the foreign and the government sector firms.

-Insert Table 1 here-

Tables 2 to 5 highlight relationship between the busyness of audit committee members and the quality of financial reporting for sub-samples foreign, government, and local private firms and for the full sample. In tables 2 to 5, the spline nodes in the horizontal columns, (a) to (h), indicate the busyness level of the audit committee members, ranging from three to ten.

-Insert Table 2 here-

In table 2, results of the Spline-1 coefficient show that for the foreign firms, listed in the Indian stock exchanges, there is a positive association between the audit committee members' busyness and the discretionary accruals. Nonetheless, this association becomes significant at the spline node six and onwards, implying that as the median directorships of audit committee members of a foreign firm turns six, the coefficient of discretionary accruals becomes significant. This result can be explained with the agency theory argument that busy audit committee members either do not have time to perform tasks entrusted to them and/or they lack the required focus to perform relatively complex tasks related to audit committees. This finding also indicates that some audit committee members may use multiple directorships as a tool to enhance their own economic interests in the market of corporate directors. As a result of the busyness of audit committee members, there is an adverse effect on the quality of financial reporting. Noticeably, the positive association between the audit committee members' busyness and the discretionary accruals continues to remain significant up-to the final cut-off point of ten, which is the maximum busyness limit as per the Companies Act of India 2013 (MCA, 2013). Therefore, this finding is in conflict with the level of multiple directorships allowed by the regulator in India. A corporate director of a publicly traded firm can be on boards of other publicly traded firms in India as long as the total of such directorships does not exceed ten. However, the Spline-1 variable indicates that the quality of financial reporting starts deteriorating only when an audit committee director of the foreign firm in India assumes six outside directorships, albeit, the law allows him/her to have ten such assignments. Therefore, when ownership structure is acknowledged, the endogenously determined busyness limit (cut-off point six) provides better insight than that of exogenous limit (ten directorships) determined by regulators.

The Spline-2 variable has been found to be significant, although at a very low level (cut-off point five). This finding implies that at a relatively low level of busyness the outside directorships accepted by an audit committee member can be beneficial to the firm in the form of better financial reporting quality. This finding can be backed up by the resource dependence theory that as the busyness level of audit committee members increases, they apply more diligence, and caution and do much improved monitoring of the managerial actions, which results in lower earning manipulation, nonetheless, this virtue cannot be obtained limitlessly by the firms. As the Spline-1 variable shows above, at node six and above the harmful effects of multiple directorships start surfacing. Similar to the findings of the Spline-1 variable, the cut-off point of five of the Spline-2 variable, upholds that an endogenously determined limit of busyness of 
directors provides better understanding of the association between multiple directorships of audit committee directors and financial reporting quality than the one prescribed by the regulators.

For the Median committee- board size ratio, measuring the intensity of busyness, the findings show that from the cut-off point three to five the committee assignments (for example, audit committee, remuneration committee, and nomination committee, and not merely serving on general boards of directors) taken up by the audit committee members of the firm in other firms successfully lowers the level of discretionary accruals, and thus improves quality of financial reports of the firm. However, this effect of this variable ceases to be significant beyond the spline node five. This result indicates that not only the number of busyness but also the nature of busyness, incorporating the demanding nature of workload in specialized committees, affects the quality of financial reporting. The above finding can also be explained with the help of the resource dependence theory (Hillman and Dalziel, 2003). The audit committee members due to their skills, expertise, experience, linkage to the external contingencies are better equipped to smother earnings manipulation practices, however, only up-to a certain limit, and beyond such limit the agency costs may neutralize beneficial effects of the resource dependence theory.

Similarly, the AC chair expertise variable is associated with the improved quality of financial information at all the nodes indicating the busyness of audit committee members. The workload of an audit committee chairperson is highly demanding and financial skills oriented (Tanyi and Smith, 2015). The results show that irrespective of the busyness level of the audit committee members, the financial expertise of the audit committee chairperson plays a significant role to improve the quality of financial data. However, at the higher level of busyness the significance level starts diminishing indicating a possible trend. Similarly, the findings of the NAS to total revenue of auditor, the measure of extended interlocking, highlights its positive association with the discretionary accrual through all the spline nodes. The rising ratio of the NAS to the total revenue earned from a given client firm implies over economic dependence of the audit firm on its client and shrinking independence of the audit committee with respect to monitoring and control of managerial actions. Zang and Emanueal (2008) also find similar results in their study. The coefficients of the Board size, Independent directors proportion and Debt-Equity ratio have been found to be insignificant. Even though a bigger board of directors is assumed to be having relatively diverse reputational capital, and is more likely to produce objective financial results (Dalton et al., 1999; Goilden and Zajac, 2001), nonetheless, ensuring the credibility of financial reporting is a highly skill based function and the mere presence of more members in the board does not automatically imply high quality financial reporting. On the contrary, the audit committee members due to their specialized skills, education and expertise have a higher level of proficiency to perform such function more efficiently. Similarly, the Independent directors proportion coefficient is also insignificant. A possible explanation of this finding is that even though an independent board is expected to reduce information asymmetries between owners and managers (Donnelly and Mulcahy, 2008) and high quality of financial reporting contributes to eliminate such asymmetries, nonetheless, the phenomenon of multiple directorships of audit 
committee members, even at lower spline nodes, may act as a limiting factor and render independent directors relatively ineffective. The same explanation also holds true for the insignificant effect of the debt-equity ratio on the financial reporting quality.

Furthermore, the $R \& D$ intensity and the Advertisement intensity variables also indicate to have favorable effects on the financial reporting quality up-to spline node eight and throughout, respectively. Both variables are indicatives of firms' growth and bonding costs of managers (Ang et al., 2000; Easterbrook, 1984). The signals indicating managers' loyalty/alignment to the firm's interests and its growth orientations have a favorable association with the objective and true financial information of the firm. The results of the variable Trade intensity show that firms having relatively active stock have better quality of financial information but not after the busyness level exceeds spline node six. This finding is similar to that of Fan and Wong (2002), and implying that firms whose stocks are traded actively have to face investors' ire relatively more if they indulge in earnings management practices. In the current paper, the firm size is measured by the log values of Market-capitalization, and the results indicate that bigger firms have lower incidence of earnings management due to fear of loss of reputation (Carey and Simnett, 2006).

-Insert Table 3 here-

Table 3 highlights the association between discretionary accruals and the busyness of audit committee members of the government owned firms in India. The coefficient of Spline-1 variable turns significantly positively at node six showing deteriorating financial reporting quality at the increased level of busyness of audit committee members. The association gets even stronger as the busyness increases further. The coefficients of Spline-2 variable remain insignificant throughout the spline nodes, highlighting that the reputational capital of directors does not play any role in improving quality of the financial data. A possible reason for such finding is that for a government owned firms the appointment of directors on its boards is relatively driven by bureaucratic factors rather than the reputational capital of directors. The coefficient of the third variable of busyness, the Median committee-board size ratio turns positive and significant at the spline node six and becomes even more significant at the subsequent spline nodes. This finding implies that not only the number of busyness of the audit committee members adversely affects the quality of financial reporting but also the nature of busyness. The outside specialized committee memberships of boards of directors can absorb a substantial amount of time and attention of the audit committee members of the firm and resultantly the financial reporting quality of the firm is adversely affected.

Similarly, the effect of the Independent directors proportion variable is favorable on the quality of financial data of the government owned firms throughout the spline nodes. The appointment of executive directors on the government owned firms is a bureaucratic matter (Sarkar and Sarkar, 2012), however, the independent directors, who also form a majority in the audit committees, may put more emphasis to improve the financial reporting quality even at a higher level of busyness in order to enhance their reputational capital. The variable Debt-equity ratio is 
having an insignificant effect on the quality of financial reporting. The government owned firms, generally, do not have the same kind of concerns in the matters pertaining to their financing. Therefore, this variable, which essentially underlines the capital structure of firms does not influence financial reporting quality irrespective of busyness of the audit committee members. Similarly, the effects of the AC chair expertise and the Board size are also insignificant. The peculiar institutional settings of the government owned firms can be attributed to these results. Similarly, the finding of the NAS to total revenue of auditor, measuring the extended interlocking, shows a positive association with the discretionary accrual throughout the spline nodes. The auditors' economic interests on client firms adversely affect the financial reporting quality at all cut-off points of audit committee members' busyness.

The coefficient of variables, the $R \& D$ intensity and the Advertisement intensity, both measuring bonding costs incurred by executives and growth orientation of firms, show their adverse effect on the financial reporting quality. Many agency theorists (for example, Jensen and Meckling, 1976; Easterbrook, 1984) have debated whether monitoring and bonding can be substitutes. A popular argument in the agency theory highlights that if agents incur bonding costs, then their alignment with the utility function followed with that of the principal increases. The findings show that bonding costs not only fail to substitute the monitoring of corporate executives but they are even associated with deteriorated financial reporting quality. Possibly, firm managers even use expenditures on advertisement and $R \& D$ to manipulate discretionary accruals for their vested interests. The insignificant coefficient of the variable Trade intensity further highlights the unique institutional settings in which the government owned firms' shares are traded. Similar to the findings in the case of foreign firms, the coefficients of the Market-capitalization indicate that bigger firms have lower incidence of earnings management due to fear of loss of reputation.

\section{-Insert Table 4 here-}

Table 4 shows the association between discretionary accruals and busyness of audit committee members of local private sector listed firms in India. The coefficient of Spline-1 variable becomes significantly positive at the spline node five and it gets even stronger as the busyness level of the audit committee members increases further. The Spline-2 variable, highlighting 'good effects' of the busyness of the audit committee members, as mentioned in the resource dependence theory, is significantly negative up-to spline node four. This finding implies that at a relatively low level of busyness, the audit committee members of local private firms in India are relatively motivated by the reputational capital effect and as a result they monitor and control managerial actions with due diligence and effectively check the objectivity and truthfulness of financial reports of firms, however, at a higher level of busyness (the spline node of five and above) they may be lacking time and focus required to perform their core responsibilities. Similarly, the coefficient of the third variable of busyness, the Median committee- board size ratio turns positive and significant at the spline node six and becomes even more significant at the subsequent spline nodes.

Similarly, the effect of the Independent directors proportion variable is favorable on the quality of financial data of the local private firms, however, not after the spline node five. The Indian 
corporate sector is dominated by the promoter owned firms, and in such firms the role of independent directors may not be effective in maintaining the quality of financial reports, especially at the higher level of busyness of audit committee members. The variable Debt-equity ratio is having significant effect on improving of financial reports throughout. Due to high relevance of debt in the capital structure of the local private sector firms in India, it is utmost important for such firms to reveal their real financial health by disclosing objective financial data of the firm in order to strengthen their ties with the institutional lenders (Sarkar and Sarkar, 2012). The increasing Debt-equity ratio implies more managerial discipline irrespective of the busyness of the audit committee of the firm. Similarly, the effect of the AC chair expertise is favorable on the quality of financial data, albeit up-to the spline node six. The financial expertise of the audit committee chairperson can play an important role in mitigating earnings management practices, however, at an increased level of the busyness of audit committee members, the coefficient turns insignificant. Similarly, the coefficient of the NAS to total revenue of auditor, measuring extended interlocking, signifies its positive association with the discretionary accrual through all the spline nodes. The rising ratio of the NAS to the total revenue earned by an audit firm from its client firm underlines over economic dependence of the audit firm on its client, and also diminishing independence of the audit committee in the matters pertaining to monitoring and control of managerial actions. The coefficient of Board size of the local private firms indicates that larger board size is associated with the enhanced financial reporting quality and this finding gets the support of Dalton et al. (1999) and (Goilden and Zajac 2001), who argue in favor of larger boards' diversity and level of reputational capital, which play an important role in better monitoring and improved financial reporting process. Furthermore, the $R \& D$ intensity and the Advertisement intensity variables also indicate their good effects on the financial reporting quality throughout and up-to spline node eight, respectively. Both variables indicate that when interests of managers are aligned with those of firms and when firms endeavor to grow, the financial reporting quality improves. Similarly, the variable Trade intensity shows that firms having relatively active stock have better quality of financial information. The local private firms having highly active stocks may invite a more negative reaction of investors if such firms do not pay any attention to improving their financial data. The coefficient of Market-capitalization variable, measuring the firm size, indicates that bigger firms have lower incidence of earnings management due to fear of loss of reputation, however, not beyond the spline node six.

\section{-Insert Table 5 here-}

Table 5 shows the association between discretionary accruals and busyness of audit committee members for the full sample. The coefficient of Spline-1 remains significantly positive throughout only when starting from the spline node six. The variable Spline-2, highlighting virtues of busyness of audit committee members, according to the resource dependence theory, is significantly negative up-to the spline node four. Furthermore, the coefficient of Median committee- board size also gets significantly positive starting from the spline node six. Overall, the analysis of the above three busyness variables reveals that at the lower level of busyness (upto the spline node four), the busyness of audit committee members helps to enhance financial reporting quality; whereas, at the relatively higher level of busyness (six and above), the same has a detrimental effect on financial reporting quality.

The Board size helps to enhance financial reporting quality but only up-to spline node six. Similarly, the Independent directors proportion affects the financial reporting quality favorably 
throughout. Similarly, the AC chair expertise is associated with improved financial information but not after the spline node seven. The coefficient of Debt-equity ratio, signifying the corporate capital structure, has an improvement effect on the quality of financial reporting up-to node five. On the other hand, the NAS to total revenue of auditor has an unfavorable effect on financial reporting quality up-to node four. Surprisingly, for all the sub-samples, this variable affects financial reporting quality adversely throughout the busyness level of audit committee members. An explanation to the above aberration observed in the full sample is that the interlocking between the promoters and audit committee members does not transform into extended interlocking due to the possible loss of reputation of audit committee directors and adverse reaction of investors.

The coefficient of the $R \& D$ intensity affects the financial reporting quality favorably throughout, whereas those of the Advertisement intensity, the Trade intensity, and the Market-capitalization (firm size) have the same effect up-to a relatively lower level of busyness (spline node four).

-Insert Table 6 here-

Table 6 summarizes the endogenously determined busyness limits of the audit committee members based on the effects of such busyness on the financial reporting quality, measured by discretionary accruals. The effects of the association between the busyness of audit committee members and the quality of financial reporting are reported in this table from the agency, and resource dependence theoretical perspectives. Neither, endogenously determined limits of busyness of sub samples nor that of the full sample are in conformity with the exogenously prescribed limits of the regulator in India.

\section{Conclusions and future research}

Shareholders and several other stakeholders of firms seek to use objective financial information in order to observe firms' actions and their effects on them, in order to make rational decisions. The audit committee, a part of the internal corporate governance mechanism of firms, aims to ensure that the financial statements and related disclosures are prepared according to the legal requirements, and accounting standards set by regulators and professional bodies. An audit committee can perform its functions efficiently, when it is able to operate independent of managerial influences. Among other things, the number of directorships (boards and committees) accepted by directors of a given firm in other firms is an important determinant of the independence of the audit committee. The agency theory argument follows that as the number of outside directorships of the audit committee members of a firm increases, their effectiveness to review financial statements, and question the managerial actions diminish. However, according to the resource dependence theory, the phenomenon of multiple directorships of the audit committee members is associated with their enhanced human and relational capital, collectively known as the reputational capital. The current paper has examined, first, whether multiple directorships of the audit committee members affect quality of financial data in India, and second, whether endogenously determined limits of busyness of the audit committee members explains their association with the financial reporting quality better than those by the exogenous limits prescribed by the regulator. In an emerging country like India, where the foreign, and local private sector have been showing continuous growth, government owned firms have been maintaining their traditional importance, and at the same time their ownership structure and other institutional settings are markedly different, it is also important to study the association between 
multiple directorships of the audit committee members and the financial reporting quality based on the sub-samples along with the full sample.

The study shows that for the foreign, government owned firms, and full sample, the busyness of audit committee members does not affect financial reporting quality adversely before the median audit committee members at the firm level turns six, however, for the local private firms, the same phenomenon is observed not before five audit committee memberships. An interesting feature of the findings of the current paper is that the agency costs, in the form of poor quality of financial reporting, proxied by the discretionary accruals, emerge before reaching the regulatory limit of maximum ten directorships. Similarly, in the current paper the endogenously determined range of multiple directorships of audit committee members also highlight their favorable effects on the financial reporting quality. The sub-samples of the foreign, local private sector firms and the full sample firms experience improvements in financial reporting quality at the lower level of busyness of the audit committee members, whereas, for the government owned firms, such beneficial effect never reaches at any point in the entire range of spline nodes. Overall, it can be concluded based on the analysis of the Spline-1 and the Spline-2 that the lower level of busyness of the audit committee members can be beneficial to firms; however, the same at the higher level of busyness can be detrimental to the financial reporting quality.

Similarly, the third variable of busyness i.e. median committee to board size, measuring the intensity of busyness, indicates mixed results. For the sub-samples of government, and local private firms and full sample, the intensity of busyness unfavorably affects the financial reporting quality at a relatively higher level of audit committee members' busyness, whereas, for the sub samples of foreign firms the favorable effect of the same variable is significant at a lower level.

The current paper contributes to the extant literature in several ways, first, the endogenously determined busyness limits explain the association between multiple directorships of audit committee members and the quality of financial reporting better than those exogenously recommended by regulators; second, despite applying the endogenous limits of busyness in the analysis for the full sample and sub-samples, the results reveal that 'one size does not fit all', that is the cut-off points of busyness highlighting the optimum level of busyness for the different ownership groups are not uniform, therefore, the current paper incorporates the institutional settings in which firms operate; third, this paper, along with the number of multiple directorships of the audit committee members in per se, also recognizes the nature of multiple directorships and analyzes their effects on the financial reporting quality, therefore, the regulator should not recommend a single upper limit of busyness of directors of a firm as such limits do not take into account the intensity of busyness of board, and committee members; and lastly, the current paper is one of the few studies in the settings of an emerging economy, such as India, and inferences drawn on the basis of the findings of this paper can be useful for countries having comparable corporate landscape.

The current paper has certain limitations too. First, the current paper is not considering alternative measures of the quality of financial information; therefore, robustness of the explained variable cannot be determined. Second, despite recognizing that the intensity of busyness is an important contribution of this paper, nonetheless, the current paper does not study the effect of busyness of the audit committee members of the firms in the same committee of other firms. The reason for this limitation is that the available data in the current study is only 
pertaining to the busyness of the audit committee members of a firm in other firms, categorized as 'boards' and 'committees', and no further break up of 'committees' is available.

Acknowledgements: I extend my sincere gratitude to my doctoral thesis supervisors Prof. Marko Järvenpää, Prof. Aila Virtanen and anonymous reviewers.

\section{References:}

Abbott, L.J., Park, Y. and Parker, S. (2000) 'The effects of audit committee activity and independence on corporate fraud', Managerial Finance, Vol. 26, No. 11, pp.55-67.

Abbott, L.J., Parker, S. and Peters, G.F. (2004) 'Audit committee characteristics and restatements', Auditing: A Journal of Practice \& Theory, Vol. 23, No. 1, pp.69-87.

Ahlberg, J.H., Nilson, E.N. and Walsh, J.L. (1967) The Theory of Splines and Their Applications, Academic Press, New York.

Ahn, S., Jiraporn, P. and Kim, Y.S. (2010) 'Multiple directorships and acquirer returns', Journal of Banking \& Finance, Vol. 34, No. 9, pp.2011-2026.

Ang, J.S., Cole, R.A. and Lin, J.W. (2000) 'Agency Costs and Ownership Structure', Journal of Finance, Vol. 55, No. 1, pp.81-106.

Antle, R. (1982) 'The Auditor As an Economic Agent', Journal of Accounting Research, Vol. 20, No. 2, pp.503-527.

Ball, R. (2009) 'Market and political/regulatory perspectives on the recent accounting scandals', Journal of Accounting Research, Vol. 47, No. 2, pp.277-323.

Beasley, M.S., Carcello, J.V., Hermanson, D.R. and Neal, T.R. (2009) 'The audit committee oversight process', Contemporary Accounting Research, Vol. 26, No. 1, pp.65-122.

Beck, P.J., Frecka, T.J. and Solomon, I. (1988) 'A model of the market for MAS and audit services: Knowledge spillovers and auditor-auditee bonding', Journal of Accounting Literature, Vol. 7, pp.50-64.

Bedard, J., Chtourou, S.M. and Courteau, L. (2004) 'The Effect of Audit Committee Expertise, Independence and Activity on Aggressive Earnings Management', Auditing: A Journal of Practice and Theory, Vol. 23, No. 2, pp.13-35.

Carey, P. and Simnett, R. (2006) 'Audit partner tenure and audit quality', The Accounting Review, Vol. 81, No. 3, pp.653-76.

Chen, J., Chou, Y., Duh, R. and Lin, Y. (2014) 'Audit Committee Director-Auditor Interlocking and Perceptions of Earnings Quality', Auditing: A Journal of Practice \& Theory, Vol. 33, No. 4, pp.41-70.

Dalton, D.R., Daily, C.M., Johnson J.L. and Ellstrand, A.E. (1999) 'Number of directors and financial performance: A meta-analysis', Academy of Management Journal, Vol. 42, pp.674-686. 
David, H. and Siew, H.T. (2003) 'Limited attention, information disclosure, and financial reporting', Journal of Accounting and Economics, Vol. 36, No. 1-3, pp.337-386.

De Boor, C. (2001) A Practical Guide to Splines, Springer-Verlag, New York.

Demsetz, H. and Lehn, K. (1985) 'The structure of corporate ownership: Causes and consequences', Journal of Political Economy, Vol. 93, No. 6, pp.1155-77.

DeZoort, F.T., Hermanson, D.R., Archambeault, D.S. and Reed, S.A. (2002) 'Audit committee effectiveness: A synthesis of the empirical audit committee literature', Journal of Accounting Literature, Vol. 21, pp.38-75.

DeZoort, F.T., Hermanson, D.R. and Houston, R.W. (2003) 'Audit committee support for auditors: The effects of materiality justification and accounting precision', Journal of Accounting and Public Policy, Vol. 22, No. 2, pp.175-199.

Dhaliwal, D.S., Naiker, V. and Navissi, F. (2010) 'The association between accruals quality and the characteristics of accounting experts and mix of expertise on audit committees', Contemporary Accounting Research, Vol. 27, No. 3, pp.787-827.

Donnelly, R. and Mulcahy, M. (2008) 'Board structure, ownership, and voluntary disclosure in Ireland', Corporate Governance: An International Review, Vol. 16, No. 5, pp.416-28.

Easterbrook, F. (1984) 'Two agency cost explanations of dividends', American Economic Review, Vol. 74, No. 4, pp.650-659.

Eysenck, M.W. and Keane, M.T. (1990) Cognitive psychology: a student's handbook, $4^{\text {th }}$ ed., Lawrence Erlbaum Associates Ltd., Hove.

Fan, J.P.H. and Wong, T.J. (2002) 'Corporate ownership structure and the informativeness of accounting earnings in East Asia', Journal of Accounting and Economics, Vol. 33, No. 3, pp.401-425.

Ferris S.P., Jagannathan M. and Pritchard A.C. (2003) 'Too busy to mind the business? Monitoring by directors with multiple board appointments', Journal of Finance, Vol. 58, No. 3, pp.1087-1111.

Fiske, S.T. (Eds.), (1995) Advanced Social Psychology, McGraw-Hill, New York.

Goilden, B.R. and Zajac, E.J. (2001) 'When will boards influence strategy? Inclination $\times$ Power = Strategic change', Strategic Management Journal, Vol. 22, pp.1087-1117.

Guest, P.M. (2009) 'The impact of board size on firm performance: evidence from the U.K.', The European Journal of Finance, Vol. 15, No. 4, pp.385-404.

He, L. and Yang, R. (2014) 'Does Industry Regulation Matter? New Evidence on Audit Committees and Earnings Management', Journal of Business Ethics, Vol. 123, No. 4, pp.573589. 
Helland, E. (2006) 'Reputational penalties and the merits of class-action securities action', The Journal of Law and Economics, Vol. 49, No. 2, pp.365-384.

Hermalin, B. and Weisbach M. (1998) 'Endogenously chosen boards of directors and their monitoring of the CEO', The American Economic Review, Vol. 88, No. 1, pp.96-118.

Hermalin, B. and Weisbach M. (2003) 'Boards of directors as an endogenously determined institution: A survey of the economic literature', Economic Policy Review, April, pp.7-26.

Hillman A.J. and Dalziel T. (2003) 'Boards of Directors and Firm Performance: Integrating Agency and Resource Dependence Perspectives', Academy of Management Review, Vol. 28, No. 3, pp.383-396.

Hundal, S. (2013) 'Independence, Expertise and Experience of Audit Committees: Some Aspects of Indian Corporate Sector', American International Journal of Social Science, Vol. 2, No. 5, pp.58-75.

Hunton, J.E. and Rose, J.M. (2008) 'Can directors' self-interests influence accounting choices? Accounting', Organizations and Society, Vol. 33, No. 7, pp.783-800.

Jensen, M. and Meckling, W.H. (1976) 'Theory of the Firm: Managerial Behavior, Agency Costs and Ownership Structure', Journal of Financial Economics, Vol. 3, No. 4, pp.305-360.

Jermias, J. and Gani, L. (2014) 'The impact of board capital and board characteristics on firm performance', The British Accounting Review, Vol. 46, No. 2, pp.135-153.

Jiraporn, P., Singh, M. and Lee, C.I. (2009) 'Ineffective corporate governance: director busyness and board committee memberships', Journal of Banking \& Finance, Vol. 33, No. 5, pp.819-828.

Johansen, T.R. and Pettersson, K. (2013) 'The impact of board interlocks on auditor choice and audit fees’, Corporate Governance: An International Review, Vol. 21, No. 3, pp.287-310.

Jones, J.J (1991) 'Earnings Management During Import Relief Investigations', Journal of Accounting Research, Vol. 29, No. 2, pp.193-228.

Kahneman, D. (1973) Attention and Effort, Prentice-Hall, Englewood Cliffs (NJ).

Kaplan, S. and Reishus, D. (1990) 'Outside directorships and corporate performance', Journal of Financial Economics, Vol. 27, No. 2, pp.389-410.

Khanna, V. and Mathew, S.J. (2010) 'The Role of Independent Directors in Controlled Firms in India: Preliminary Interview Evidence', National Law School of India Review, Vol. 22, No. 1, pp.35-66.

Klein, A. (2002) 'Audit Committee, Board of Director Characteristics, and Earnings Management', Journal of Accounting and Economics, Vol. 33, No. 3, pp.375-400. 
Linck, J.S., Netter, J.M. and Yang, T. (2009) 'The effects and unintended consequences of the Sarbanes-Oxley Act on the supply and demand for directors', Review of Financial Studies, Vol. 22, No. 8, pp.3287-3328.

Marciukaityte D. and Szewczyk S.H. (2011) 'Financing Decisions and Discretionary Accruals: Managerial Manipulation or Managerial Overoptimism', Review of Behavioral Finance, Vol. 3, No. 2, pp.91-114.

MCA (1956) The Compabies Act 1956 [act no. 1 of 1956]. [online] Government of India, New Delhi. http://www.mca.gov.in/Ministry/pdf/Companies_Act_1956_13jun2011.pdf. (Accessed 24 January 2014)

MCA (2009) The Companies Bill (2009). [online] Government of India, New Delhi. http://www.mca.gov.in/Ministry/actsbills/pdf/Companies_Bill_2009_24Aug2009.pdf (Accessed 23 July 2014)

MCA (2013) The Companies Act (2013). [online] Government of India, New Delhi. http://www.mca.gov.in/Ministry/pdf/CompaniesAct2013.pdf (Accessed 24 July 2014)

Méndez, C. F., Pathan, S. and García, R.A. (2015) 'Monitoring capabilities of busy and overlap directors: Evidence from Australia', Pacific-Basin Finance Journal, Vol. 35 (Part A), pp.444469.

NYSE (2013) NYSE Listed Company Manual. [online] New York Stock Exchange http://nysemanual.nyse.com/lcm (Accessed 24 January 2014)

Pearce J. and Zahra S. (1992) 'Board Composition from a Strategic Contingency Perspective', Journal of Management Studies, Vol. 29, No. 4, pp.411-38.

Perry, T. and Peyer, U. (2005) 'Board seat accumulation by executives: a shareholder's perspective', The Journal of Finance, Vol. 60, No. 4, pp.2084-2123.

Pfeffer, J. and Salancik, G. (1978.) The External Control of Organizations: A Resource Dependence Perspective, Harper \& Row, New York.

Raghunandan, K. and Rama, D. (2007) 'Determinants of audit committee diligence', Accounting Horizons, Vol. 21, No. 3, pp.265-97.

Sarens, G., and Abdolmohammadi, M.J. (2011) 'Monitoring Effects of the Internal Audit Function: Agency Theory versus other Explanatory Variables', International Journal of Auditing, Vol. 15, No. 1, pp.1-20.

Sarkar, J. and Sarkar, S. (2013) Report on Functioning in India State of Auditor and Audit Committee, National Stock Exchange of India Limited (NSE) Centre for Excellence in Corporate Governance, June.

Sarkar, J. and Sarkar, S. (2012) Corporate Governance Reforms in India, Sage Publications, New Delhi. 
SEBI (2000) Corporate Governance in listed Companies - Clause 49 of the Listing Agreement (Original Clause 49). [online] Securities and Exchange Board of India. http://www.sebi.gov.in/circulars/2000/CIR102000.html (Accessed 23 July 2014).

SEBI (2004) Corporate Governance in listed Companies - Clause 49 of the Listing Agreement (Revised Clause 49). [online] Securities and Exchange Board of India. http://www.sebi.gov.in/circulars/2004/cfdcir0104.pdf (Accessed 23 July 2014).

SEC (1999) Report and Recommendations of Blue Ribbon Committee (BRC) on Improving the Effectiveness of Corporate Audit Committees, Washington DC, NYSE NASDAQ and AMEX.

SEC (2003) Standards Relating to Listed Company Audit Committees Securities Act Release No. 33-8220 (SEC LEXIS 846-SEC Audit Committee Release). [online] Securities and Exchange Commission. http://www.sec.gov/rules/final/33-8220.htm (Accessed 12 March 2013).

Sharma, V.D. and Iselin, E.R. (2012) 'The Association between Audit Committee MultipleDirectorships, Tenure, and Financial Misstatements', Auditing: A Journal of Practice \& Theory, Vol. 31, No. 3, pp.149-175.

Sharma, V.D. Naiker, V. and Lee B. (2009) 'Determinants of audit committee meeting frequency: Evidence from a voluntary governance system', Accounting Horizons, Vol. 23, No. 3, pp.245-263.

Simunic, D. (1984) 'Auditing, consulting, and auditor independence', Journal of Accounting Research, Vol. 22, No. 2, pp.679-702.

Skinner, D. and Srinavasan, S. (2012) 'Audit quality and auditor reputation: Evidence from Japan', The Accounting Review, Vol. 87, No. 5, pp.1737-65.

SOX Act (2002) Standards Relating to Listed Company Audit Committees. [online] Securities and Exchange Commission. http://www.sec.gov/rules/final/33-8220.htm. (Accessed 23 July 2014.

Vafeas, N. (1999) 'Board meeting frequency and firm performance', Journal of Financial Economics, Vol. 53, No. 1, pp.113-142.

Vafeas, N. (2001) 'Research notes on audit committee appointments', Auditing: A Journal of Practice \& Theory, No. 20, Vol. 1, pp.197-207.

Watts, R. and Zimmerman, J. (1983) 'Agency problems, auditing, and the theory of the firm: Some evidence', Journal of Law and Economics, Vol. 26, No. 3, pp.613-33.

Watts, R. and Zimmerman, J. (1986) Positive Accounting Theory. Prentice Hall, Englewood Cliffs (NJ).

Zang, B. and Emanueal, S. (2008) 'The provision of non-audit services and earnings conservatism: Do New Zealand auditors compromise their independence?', Accounting Research Journal, Vol. 21, No. 2, pp.195-221. 
Table 1: Comparison of coefficients of discretionary accruals for sub-samples and overall sample (Data: 2004-12)

\begin{tabular}{|c|c|c|c|c|c|}
\hline Coefficients $^{\mathrm{a}}$ & $\begin{array}{l}\text { Expected } \\
\text { Sign }\end{array}$ & $\begin{array}{l}\text { Sub-sample } 1 \\
\text { (Private Local) }\end{array}$ & $\begin{array}{l}\text { Sub-sample } 2 \\
\text { (Foreign) }\end{array}$ & $\begin{array}{l}\text { Sub-sample } 3 \\
\text { (Government) }\end{array}$ & $\begin{array}{l}\text { Overall } \\
\text { sample }\end{array}$ \\
\hline$\alpha_{1}$ & $?$ & $\begin{array}{l}-1210.551^{* *} \\
(-11.42)\end{array}$ & $\begin{array}{l}1150.293^{* * *} \\
(24.11)\end{array}$ & $\begin{array}{l}2352.319^{* *} \\
(7.88)\end{array}$ & $\begin{array}{l}-0.007 \\
(-0.881)\end{array}$ \\
\hline$\alpha_{2}$ & $+\mathrm{ve}$ & $\begin{array}{l}0.521^{* * *} \\
(3.78)\end{array}$ & $\begin{array}{l}2.563^{* * * *} \\
(173.77)\end{array}$ & $\begin{array}{l}0.011 \\
(0.712)\end{array}$ & $\begin{array}{l}0.265^{* *} \\
(13.235)\end{array}$ \\
\hline$\alpha_{3}$ & -ve & $\begin{array}{l}-0.547^{* *} \\
(-3.98)\end{array}$ & $\begin{array}{l}-0.021^{* *} \\
(-6.22)\end{array}$ & $\begin{array}{l}0.002 \\
(0.121)\end{array}$ & $\begin{array}{l}-0.223^{* *} \\
(-11.191)\end{array}$ \\
\hline $\begin{array}{ll}\mathrm{N} & \text { (Firm- } \\
\text { Years) }\end{array}$ & & 2376 & 585 & 772 & 3733 \\
\hline
\end{tabular}

${ }^{a}$ Jones (1991) expectation model (1991) model has been applied to estimate coefficients of discretionary accruals. The model is as below:

$T A_{i t} / A_{i t-1}=\alpha_{1}\left(1 / A_{i t-1}\right)+\alpha_{2}\left(\Delta R E V_{i t} / A_{i t-1}\right)+\alpha_{3}\left(P P E_{i t} / A_{i t-1}\right)+\varepsilon_{i t}$

$* * * \mathrm{p}<0.001, * * \mathrm{p}<0.01,{ }^{*} \mathrm{p}<0.05$, and $\dagger \mathrm{p}<0.1$ (t-statistics appear in parentheses) 
Table 2: Association between discretionary accruals and busyness of audit committee members-foreign firms (Data: 2004-12)

\begin{tabular}{|c|c|c|c|c|c|c|c|c|}
\hline $\begin{array}{l}\text { Discretionary variable } \\
\text { (dependent variable) }\end{array}$ & (a) & (b) & (c) & (d) & (e) & (f) & (g) & (h) \\
\hline & $\begin{array}{l}\text { Spline } \\
\text { Node }=3\end{array}$ & $\begin{array}{l}\text { Spline } \\
\text { Node }=4\end{array}$ & $\begin{array}{l}\text { Spline } \\
\text { Node }=5\end{array}$ & $\begin{array}{l}\text { Spline } \\
\text { Node }=6\end{array}$ & $\begin{array}{l}\text { Spline } \\
\text { Node }=7\end{array}$ & $\begin{array}{l}\text { Spline } \\
\text { Node }=8\end{array}$ & $\begin{array}{l}\text { Spline } \\
\text { Node }=9\end{array}$ & $\begin{array}{l}\text { Spline } \\
\text { Node }=10\end{array}$ \\
\hline Intercept & $\begin{array}{l}31.222^{* * *} \\
(126.387)\end{array}$ & $\begin{array}{l}31.118^{* * *} \\
(123.686)\end{array}$ & $\begin{array}{l}31.118^{* * *} \\
(123.686)\end{array}$ & $\begin{array}{l}30.101^{* * *} \\
(118.118)\end{array}$ & $\begin{array}{l}29.229^{* * *} \\
(114.283)\end{array}$ & $\begin{array}{l}26.056^{* * *} \\
(110.009)\end{array}$ & $\begin{array}{l}26.056^{* * *} \\
(110.009)\end{array}$ & $\begin{array}{l}26.033^{* * *} \\
(108.119)\end{array}$ \\
\hline Spline-1 & $\begin{array}{l}0.131 \\
(1.141)\end{array}$ & $\begin{array}{l}0.142 \\
(1.152)\end{array}$ & $\begin{array}{l}0.147 \\
(1.168)\end{array}$ & $\begin{array}{l}0.160^{\dagger} \\
(1.477)\end{array}$ & $\begin{array}{l}0.205^{*} \\
(2.045)\end{array}$ & $\begin{array}{l}0.206^{*} \\
(2.053)\end{array}$ & $\begin{array}{l}0.206^{*} \\
(2.053)\end{array}$ & $\begin{array}{l}0.206^{*} \\
(2.056)\end{array}$ \\
\hline Spline-2 & $\begin{array}{l}-0.155^{\dagger} \\
(-1.432)\end{array}$ & $\begin{array}{l}-0.155^{\dagger} \\
(-1.432)\end{array}$ & $\begin{array}{l}-0.157^{\dagger} \\
(-1.439)\end{array}$ & $\begin{array}{l}-0.142 \\
(-1.149)\end{array}$ & $\begin{array}{l}-0.131 \\
(-1.141)\end{array}$ & $\begin{array}{l}-0.129 \\
(-1.129)\end{array}$ & $\begin{array}{l}-0.121 \\
(-1.117)\end{array}$ & $\begin{array}{l}-0.121 \\
(-1.117)\end{array}$ \\
\hline $\begin{array}{ll}\text { Median } & \text { committee- } \\
\text { board size } & \end{array}$ & $\begin{array}{l}-0.189^{*} \\
(-1.952)\end{array}$ & $\begin{array}{l}-0.167^{\dagger} \\
(-1.537)\end{array}$ & $\begin{array}{l}-0.159^{\dagger} \\
(-1.465)\end{array}$ & $\begin{array}{l}-0.149 \\
(-1.184)\end{array}$ & $\begin{array}{l}-0.142 \\
(-1.152)\end{array}$ & $\begin{array}{l}-0.140 \\
(-1.137)\end{array}$ & $\begin{array}{l}-0.140 \\
(-1.137)\end{array}$ & $\begin{array}{l}-0.140 \\
(-1.137)\end{array}$ \\
\hline Board size & $\begin{array}{l}0.001 \\
(0.058)\end{array}$ & $\begin{array}{l}0.001 \\
(0.058)\end{array}$ & $\begin{array}{l}0.001 \\
(0.058)\end{array}$ & $\begin{array}{l}0.001 \\
(0.058)\end{array}$ & $\begin{array}{l}0.001 \\
(0.058)\end{array}$ & $\begin{array}{l}0.001 \\
(0.058)\end{array}$ & $\begin{array}{l}0.001 \\
(0.058)\end{array}$ & $\begin{array}{l}0.001 \\
(0.058)\end{array}$ \\
\hline $\begin{array}{l}\text { Independent directors } \\
\text { proportion }\end{array}$ & $\begin{array}{l}0.001 \\
(0.866)\end{array}$ & $\begin{array}{l}0.001 \\
(0.866)\end{array}$ & $\begin{array}{l}0.001 \\
(0.866)\end{array}$ & $\begin{array}{l}0.001 \\
(0.866)\end{array}$ & $\begin{array}{l}0.001 \\
(0.866)\end{array}$ & $\begin{array}{l}0.001 \\
(0.866)\end{array}$ & $\begin{array}{l}0.001 \\
(0.866)\end{array}$ & $\begin{array}{l}0.001 \\
(0.866)\end{array}$ \\
\hline AC chair expertise & $\begin{array}{l}-0.269^{* *} \\
(-2.832)\end{array}$ & $\begin{array}{l}-0.269^{* *} \\
(-2.834)\end{array}$ & $\begin{array}{l}-0.269^{* *} \\
(-2.832)\end{array}$ & $\begin{array}{l}-0.257^{*} \\
(-2.223)\end{array}$ & $\begin{array}{l}-0.227^{*} \\
(-2.129)\end{array}$ & $\begin{array}{l}-0.228^{*} \\
(-2.138)\end{array}$ & $\begin{array}{l}-0.226^{*} \\
(-2.111)\end{array}$ & $\begin{array}{l}-0.226^{*} \\
(-2.111)\end{array}$ \\
\hline R\&D intensity & $\begin{array}{l}-0.205^{*} \\
(-2.048)\end{array}$ & $\begin{array}{l}-0.205^{*} \\
(-2.048)\end{array}$ & $\begin{array}{l}-0.197^{*} \\
(-1.996)\end{array}$ & $\begin{array}{l}-0.167^{\dagger} \\
(-1.612)\end{array}$ & $\begin{array}{l}-0.167^{\dagger} \\
(-1.612)\end{array}$ & $\begin{array}{l}-0.167^{\dagger} \\
(-1.611)\end{array}$ & $\begin{array}{l}-0.147 \\
(-1.169)\end{array}$ & $\begin{array}{l}-0.147 \\
(-1.169)\end{array}$ \\
\hline $\begin{array}{l}\text { Advertisement } \\
\text { intensity }\end{array}$ & $\begin{array}{l}-0.011^{* *} \\
(-8.465)\end{array}$ & $\begin{array}{l}-0.013^{* *} \\
(-8.667)\end{array}$ & $\begin{array}{l}-0.013^{* *} \\
(-8.667)\end{array}$ & $\begin{array}{l}-0.009^{* *} \\
(-6.056)\end{array}$ & $\begin{array}{l}-0.009^{* *} \\
(-6.056)\end{array}$ & $\begin{array}{l}-0.005^{* *} \\
(-4.998)\end{array}$ & $\begin{array}{l}-0.001^{*} \\
(-2.222)\end{array}$ & $\begin{array}{l}-0.001^{*} \\
(-2.219)\end{array}$ \\
\hline Trade intensity & $\begin{array}{l}-0.001^{\dagger} \\
(-1.537)\end{array}$ & $\begin{array}{l}-0.001^{\dagger} \\
(-1.538)\end{array}$ & $\begin{array}{l}-0.001^{\dagger} \\
(-1.538)\end{array}$ & $\begin{array}{l}-0.001^{\dagger} \\
(-1.538)\end{array}$ & $\begin{array}{l}0.000 \\
(-1.154)\end{array}$ & $\begin{array}{l}0.000 \\
(-1.154)\end{array}$ & $\begin{array}{l}0.000 \\
(-1.154)\end{array}$ & $\begin{array}{l}0.000 \\
(-1.154)\end{array}$ \\
\hline Debt-Equity ratio & $\begin{array}{l}0.000 \\
(0.091)\end{array}$ & $\begin{array}{l}0.000 \\
(0.091)\end{array}$ & $\begin{array}{l}0.000 \\
(0.091)\end{array}$ & $\begin{array}{l}0.000 \\
(0.091)\end{array}$ & $\begin{array}{l}0.000 \\
(0.091)\end{array}$ & $\begin{array}{l}0.000 \\
(0.091)\end{array}$ & $\begin{array}{l}0.000 \\
(0.091)\end{array}$ & $\begin{array}{l}0.000 \\
(0.091)\end{array}$ \\
\hline Market-capitalization & $\begin{array}{l}-0.334^{* *} \\
(-5.435)\end{array}$ & $\begin{array}{l}-0.312^{* *} \\
(-5.257)\end{array}$ & $\begin{array}{l}-0.253^{* *} \\
(-2.442)\end{array}$ & $\begin{array}{l}-0.223^{*} \\
(-2.053)\end{array}$ & $\begin{array}{l}-0.223^{*} \\
(-2.053)\end{array}$ & $\begin{array}{l}-0.223^{*} \\
(-2.053)\end{array}$ & $\begin{array}{l}-0.179^{\dagger} \\
(-1.623)\end{array}$ & $\begin{array}{l}-0.167^{\dagger} \\
(-1.545)\end{array}$ \\
\hline $\begin{array}{l}\text { NAS to total revenue } \\
\text { of auditor }\end{array}$ & $\begin{array}{l}0.195^{*} \\
(2.011)\end{array}$ & $\begin{array}{l}0.195^{*} \\
(2.011)\end{array}$ & $\begin{array}{l}0.195^{*} \\
(2.011)\end{array}$ & $\begin{array}{l}0.195^{*} \\
(2.011)\end{array}$ & $\begin{array}{l}0.195^{*} \\
(2.011)\end{array}$ & $\begin{array}{l}0.195^{*} \\
(2.011)\end{array}$ & $\begin{array}{l}0.195^{*} \\
(2.011)\end{array}$ & $\begin{array}{l}0.195^{*} \\
(2.011)\end{array}$ \\
\hline Adjusted $\mathrm{R}^{2}$ & 0.42 & 0.44 & 0.44 & 0.42 & 0.42 & 0.44 & 0.45 & 0.45 \\
\hline N (Firm-Years) & 585 & 585 & 585 & 585 & 585 & 585 & 585 & 585 \\
\hline
\end{tabular}

Note: \#OLS estimates are shown in above table (t-statistics appear in parentheses).

$* * * \mathrm{p}<0.001, * * \mathrm{p}<0.01, * \mathrm{p}<0.05$, and $\dagger \mathrm{p}<0.1$ 
Table 3: Association between discretionary accruals and busyness of audit committee members-government firms (Data: 2004-12)

\begin{tabular}{|c|c|c|c|c|c|c|c|c|}
\hline $\begin{array}{l}\text { Discretionary variable } \\
\text { (dependent variable) }\end{array}$ & (a) & (b) & (c) & (d) & (e) & (f) & (g) & (h) \\
\hline & $\begin{array}{l}\text { Spline } \\
\text { Node }=3\end{array}$ & $\begin{array}{l}\text { Spline } \\
\text { Node }=4\end{array}$ & $\begin{array}{l}\text { Spline } \\
\text { Node }=5\end{array}$ & $\begin{array}{l}\text { Spline } \\
\text { Node }=6\end{array}$ & $\begin{array}{l}\text { Spline } \\
\text { Node }=7\end{array}$ & $\begin{array}{l}\text { Spline } \\
\text { Node }=8\end{array}$ & $\begin{array}{l}\text { Spline } \\
\text { Node }=9\end{array}$ & $\begin{array}{l}\text { Spline } \\
\text { Node }=10\end{array}$ \\
\hline Intercept & $\begin{array}{l}9.998^{* * *} \\
(29.086)\end{array}$ & $\begin{array}{l}9.998^{* * *} \\
(29.086)\end{array}$ & $\begin{array}{l}9.972^{* * *} \\
(26.183)\end{array}$ & $\begin{array}{l}9.961^{* * *} \\
(23.118)\end{array}$ & $\begin{array}{l}9.961^{* * *} \\
(23.118)\end{array}$ & $\begin{array}{l}9.961^{* * *} \\
(23.118)\end{array}$ & $\begin{array}{l}9.961^{* * *} \\
(23.118)\end{array}$ & $\begin{array}{l}9.961^{* * *} \\
(23.118)\end{array}$ \\
\hline Spline-1 & $\begin{array}{l}0.831 \\
(1.121)\end{array}$ & $\begin{array}{l}0.842 \\
(1.172)\end{array}$ & $\begin{array}{l}0.847 \\
(1.221)\end{array}$ & $\begin{array}{l}0.972^{\dagger} \\
(1.621)\end{array}$ & $\begin{array}{l}1.124^{*} \\
(2.123)\end{array}$ & $\begin{array}{l}1.132^{* *} \\
(2.636)\end{array}$ & $\begin{array}{l}1.132^{* *} \\
(2.636)\end{array}$ & $\begin{array}{l}1.132^{* *} \\
(2.636)\end{array}$ \\
\hline Spline-2 & $\begin{array}{l}-0.001 \\
(-0.942)\end{array}$ & $\begin{array}{l}-0.001 \\
(-0.942)\end{array}$ & $\begin{array}{l}-0.001 \\
(-0.942)\end{array}$ & $\begin{array}{l}-0.001 \\
(-0.942)\end{array}$ & $\begin{array}{l}-0.001 \\
(-0.942)\end{array}$ & $\begin{array}{l}-0.001 \\
(-0.942)\end{array}$ & $\begin{array}{l}-0.001 \\
(-0.942)\end{array}$ & $\begin{array}{l}-0.001 \\
(-0.942)\end{array}$ \\
\hline $\begin{array}{l}\text { Median committee- board } \\
\text { size }\end{array}$ & $\begin{array}{l}0.842 \\
(1.267)\end{array}$ & $\begin{array}{l}0.842 \\
(1.267)\end{array}$ & $\begin{array}{l}0.842 \\
(1.267)\end{array}$ & $\begin{array}{l}1.017^{*} \\
(2.239)\end{array}$ & $\begin{array}{l}1.038^{* *} \\
(3.771)\end{array}$ & $\begin{array}{l}1.038^{* *} \\
(3.771)\end{array}$ & $\begin{array}{l}1.258^{* *} \\
(8.668)\end{array}$ & $\begin{array}{l}1.269^{* *} \\
(9.771)\end{array}$ \\
\hline Board size & $\begin{array}{l}-0.001 \\
(-0.619)\end{array}$ & $\begin{array}{l}-0.001 \\
(-0.619)\end{array}$ & $\begin{array}{l}-0.001 \\
(-0.619)\end{array}$ & $\begin{array}{l}-0.001 \\
(-0.619)\end{array}$ & $\begin{array}{l}-0.001 \\
(-0.619)\end{array}$ & $\begin{array}{l}-0.001 \\
(-0.619)\end{array}$ & $\begin{array}{l}-0.001 \\
(-0.619)\end{array}$ & $\begin{array}{l}-0.001 \\
(-0.619)\end{array}$ \\
\hline $\begin{array}{ll}\begin{array}{l}\text { Independent } \\
\text { proportion }\end{array} & \text { directors } \\
\end{array}$ & $\begin{array}{l}-2.229^{* * *} \\
(4.026)\end{array}$ & $\begin{array}{l}-2.237^{* *} \\
(4.817)\end{array}$ & $\begin{array}{l}-2.242^{* *} \\
(5.026)\end{array}$ & $\begin{array}{l}-2.242^{* *} \\
(5.026)\end{array}$ & $\begin{array}{l}-2.244^{* *} \\
(5.087)\end{array}$ & $\begin{array}{l}-2.254^{* *} \\
(5.126)\end{array}$ & $\begin{array}{l}-2.256^{* *} \\
(5.137)\end{array}$ & $\begin{array}{l}-2.267^{* *} \\
(5.289)\end{array}$ \\
\hline AC chair expertise & $\begin{array}{l}-0.063 \\
(-1.089)\end{array}$ & $\begin{array}{l}-0.063 \\
(-1.089)\end{array}$ & $\begin{array}{l}-0.063 \\
(-1.089)\end{array}$ & $\begin{array}{l}-0.066 \\
(-1.093)\end{array}$ & $\begin{array}{l}-0.061 \\
(-1.044)\end{array}$ & $\begin{array}{l}-0.053 \\
(-1.001)\end{array}$ & $\begin{array}{l}-0.053 \\
(-1.001)\end{array}$ & $\begin{array}{l}-0.053 \\
(-1.001)\end{array}$ \\
\hline $\mathrm{R} \& \mathrm{D}$ intensity & $\begin{array}{l}1.031^{*} \\
(2.048)\end{array}$ & $\begin{array}{l}1.029^{*} \\
(2.008)\end{array}$ & $\begin{array}{l}1.028^{*} \\
(1.994))\end{array}$ & $\begin{array}{l}1.026^{*} \\
(1.848)\end{array}$ & $\begin{array}{l}1.026^{*} \\
(1.848)\end{array}$ & $\begin{array}{l}1.021^{*} \\
(1.778)\end{array}$ & $\begin{array}{l}1.012^{*} \\
(1.665)\end{array}$ & $\begin{array}{l}1.012^{*} \\
(1.665)\end{array}$ \\
\hline Advertisement intensity & $\begin{array}{l}1.213^{* *} \\
(8.267) \\
\end{array}$ & $\begin{array}{l}1.213^{* *} \\
(8.267) \\
\end{array}$ & $\begin{array}{l}1.213^{* *} \\
(8.267) \\
\end{array}$ & $\begin{array}{l}1.212^{* *} \\
(8.203) \\
\end{array}$ & $\begin{array}{l}1.210^{* *} \\
(8.056) \\
\end{array}$ & $\begin{array}{l}1.207^{* *} \\
(7.765) \\
\end{array}$ & $\begin{array}{l}1.206^{* *} \\
(7.722) \\
\end{array}$ & $\begin{array}{l}1.206^{* *} \\
(7.722)\end{array}$ \\
\hline Trade intensity & $\begin{array}{l}0.000 \\
(-1.184)\end{array}$ & $\begin{array}{l}0.000 \\
(-1.184)\end{array}$ & $\begin{array}{l}0.000 \\
(-1.184)\end{array}$ & $\begin{array}{l}0.000 \\
(-1.184)\end{array}$ & $\begin{array}{l}0.000 \\
(-1.184)\end{array}$ & $\begin{array}{l}0.000 \\
(-1.184)\end{array}$ & $\begin{array}{l}0.000 \\
(-1.184)\end{array}$ & $\begin{array}{l}0.000 \\
(-1.184)\end{array}$ \\
\hline Debt-Equity ratio & $\begin{array}{l}0.000 \\
(0.313)\end{array}$ & $\begin{array}{l}0.000 \\
(0.313)\end{array}$ & $\begin{array}{l}0.000 \\
(0.313)\end{array}$ & $\begin{array}{l}0.000 \\
(0.313)\end{array}$ & $\begin{array}{l}0.000 \\
(0.313)\end{array}$ & $\begin{array}{l}0.000 \\
(0.313)\end{array}$ & $\begin{array}{l}0.000 \\
(0.313)\end{array}$ & $\begin{array}{l}0.000 \\
(0.313)\end{array}$ \\
\hline Market-capitalization & $\begin{array}{l}-0.352^{* *} \\
(-5.039) \\
\end{array}$ & $\begin{array}{l}-0.352^{* *} \\
(-5.039) \\
\end{array}$ & $\begin{array}{l}-0.352^{* *} \\
(-5.039) \\
\end{array}$ & $\begin{array}{l}-0.353^{* *} \\
(-5.117) \\
\end{array}$ & $\begin{array}{l}-0.354^{* *} \\
(-5.276)\end{array}$ & $\begin{array}{l}-0.354^{* *} \\
(-5.276) \\
\end{array}$ & $\begin{array}{l}-0.352^{* *} \\
(-5.038) \\
\end{array}$ & $\begin{array}{l}-0.352^{* *} \\
(-5.037)\end{array}$ \\
\hline $\begin{array}{l}\text { NAS to total revenue of } \\
\text { auditor }\end{array}$ & $\begin{array}{l}0.525^{* *} \\
(7.631) \\
\end{array}$ & $\begin{array}{l}0.525^{* *} \\
(7.631) \\
\end{array}$ & $\begin{array}{l}0.525^{* *} \\
(7.631) \\
\end{array}$ & $\begin{array}{l}0.525^{* *} \\
(7.631) \\
\end{array}$ & $\begin{array}{l}0.525^{* *} \\
(7.631) \\
\end{array}$ & $\begin{array}{l}0.525^{* *} \\
(7.631) \\
\end{array}$ & $\begin{array}{l}0.525^{* *} \\
(7.631) \\
\end{array}$ & $\begin{array}{l}0.525^{* *} \\
(7.631) \\
\end{array}$ \\
\hline Adjusted $\mathrm{R}^{2}$ & 0.33 & 0.36 & 0.36 & 0.35 & 0.34 & 0.36 & 0.36 & 0.35 \\
\hline N (Firm-Years) & 772 & 772 & 772 & 772 & 772 & 772 & 772 & 772 \\
\hline
\end{tabular}

Note: \#OLS estimates are shown in above table (t-statistics appear in parentheses).

$* * * \mathrm{p}<0.001, * * \mathrm{p}<0.01, * \mathrm{p}<0.05$, and $\dagger \mathrm{p}<0.1$ 
Table 4: Association between discretionary accruals and busyness of audit committee members-private firms (Data: 2004-12)

\begin{tabular}{|c|c|c|c|c|c|c|c|c|}
\hline $\begin{array}{l}\text { Discretionary variable } \\
\text { (dependent variable) }\end{array}$ & (a) & (b) & (c) & (d) & (e) & (f) & (g) & (h) \\
\hline & $\begin{array}{l}\text { Spline } \\
\text { Node }=3\end{array}$ & $\begin{array}{l}\text { Spline } \\
\text { Node }=4\end{array}$ & $\begin{array}{l}\text { Spline } \\
\text { Node }=5\end{array}$ & $\begin{array}{l}\text { Spline } \\
\text { Node }=6\end{array}$ & $\begin{array}{l}\text { Spline } \\
\text { Node }=7\end{array}$ & $\begin{array}{l}\text { Spline } \\
\text { Node }=8\end{array}$ & $\begin{array}{l}\text { Spline } \\
\text { Node }=9\end{array}$ & $\begin{array}{l}\text { Spline } \\
\text { Node }=10\end{array}$ \\
\hline Intercept & $\begin{array}{l}10.281^{* * *} \\
(80.650)\end{array}$ & $\begin{array}{l}10.293^{* * *} \\
(80.723)\end{array}$ & $\begin{array}{l}10.311^{* * *} \\
(81.293)\end{array}$ & $\begin{array}{l}10.313^{* * *} \\
(81.446)\end{array}$ & $\begin{array}{l}10.311^{* * *} \\
(81.293)\end{array}$ & $\begin{array}{l}10.311^{* * *} \\
(81.293)\end{array}$ & $\begin{array}{l}10.313^{* * *} \\
(81.446)\end{array}$ & $\begin{array}{l}10.313^{* * *} \\
(81.446)\end{array}$ \\
\hline Spline-1 & $\begin{array}{l}0.423 \\
(1.223) \\
\end{array}$ & $\begin{array}{l}0.427 \\
(1.257)\end{array}$ & $\begin{array}{l}0.511^{\dagger} \\
(1.588)\end{array}$ & $\begin{array}{l}0.823^{*} \\
(2.319)\end{array}$ & $\begin{array}{l}1.106^{* *} \\
(6.123)\end{array}$ & $\begin{array}{l}1.132^{* *} \\
(8.636)\end{array}$ & $\begin{array}{l}1.132^{* *} \\
(8.636)\end{array}$ & $\begin{array}{l}1.133^{* *} \\
(8.707)\end{array}$ \\
\hline Spline-2 & $\begin{array}{l}-0.951^{\dagger} \\
(-1.542)\end{array}$ & $\begin{array}{l}-0.951^{\dagger} \\
(-1.542)\end{array}$ & $\begin{array}{l}-0.821 \\
(-1.212)\end{array}$ & $\begin{array}{l}-0.819 \\
(-1.142)\end{array}$ & $\begin{array}{l}-0.808 \\
(-1.117)\end{array}$ & $\begin{array}{l}-0.801 \\
(-1.009)\end{array}$ & $\begin{array}{l}-0.801 \\
(-1.009)\end{array}$ & $\begin{array}{l}-0.801 \\
(-1.009)\end{array}$ \\
\hline $\begin{array}{l}\text { Median committee- board } \\
\text { size }\end{array}$ & $\begin{array}{l}0.542 \\
(1.137)\end{array}$ & $\begin{array}{l}0.616 \\
(1.202)\end{array}$ & $\begin{array}{l}0.736 \\
(1.279)\end{array}$ & $\begin{array}{l}1.012^{*} \\
(2.023)\end{array}$ & $\begin{array}{l}1.023^{* *} \\
(5.971)\end{array}$ & $\begin{array}{l}1.023^{* *} \\
(5.971)\end{array}$ & $\begin{array}{l}1.046^{* *} \\
(6.467)\end{array}$ & $\begin{array}{l}1.046^{* *} \\
(6.467)\end{array}$ \\
\hline Board size & $\begin{array}{l}-0.246^{\dagger} \\
(-1.319)\end{array}$ & $\begin{array}{l}-0.297^{\dagger} \\
(-1.489)\end{array}$ & $\begin{array}{l}-0.321^{*} \\
(-2.219)\end{array}$ & $\begin{array}{l}-0.593^{* *} \\
(-3.787)\end{array}$ & $\begin{array}{l}-1.116^{* *} \\
(-8.227)\end{array}$ & $\begin{array}{l}-1.213^{* *} \\
(-9.852)\end{array}$ & $\begin{array}{l}-1.229^{* *} \\
(-10.511)\end{array}$ & $\begin{array}{l}-1.237^{* *} \\
(-10.819)\end{array}$ \\
\hline $\begin{array}{ll}\begin{array}{l}\text { Independent } \\
\text { proportion }\end{array} & \text { directors } \\
\end{array}$ & $\begin{array}{l}-0.767^{\dagger} \\
(1.526)\end{array}$ & $\begin{array}{l}-0.642^{\dagger} \\
(1.301)\end{array}$ & $\begin{array}{l}-0.617^{\dagger} \\
(1.287)\end{array}$ & $\begin{array}{l}-0.526 \\
(1.209)\end{array}$ & $\begin{array}{l}-0.516 \\
(1.171)\end{array}$ & $\begin{array}{l}-0.507 \\
(1.089)\end{array}$ & $\begin{array}{l}-0.492 \\
(0.847)\end{array}$ & $\begin{array}{l}-0.488 \\
(0.809)\end{array}$ \\
\hline AC chair expertise & $\begin{array}{l}-0.937^{*} \\
(-2.299)\end{array}$ & $\begin{array}{l}-0.877^{*} \\
(-1.889) \\
\end{array}$ & $\begin{array}{l}-0.863^{*} \\
(-1.733) \\
\end{array}$ & $\begin{array}{l}-0.856^{\dagger} \\
(-1.547)\end{array}$ & $\begin{array}{l}-0.721 \\
(-1.167) \\
\end{array}$ & $\begin{array}{l}-0.662 \\
(-1.023)\end{array}$ & $\begin{array}{l}-0.653 \\
(-0.901)\end{array}$ & $\begin{array}{l}-0.637 \\
(-0.827) \\
\end{array}$ \\
\hline R\&D intensity & $\begin{array}{l}-1.431^{* *} \\
(9.248)\end{array}$ & $\begin{array}{l}-1.414^{* *} \\
(9.057)\end{array}$ & $\begin{array}{l}-1.313^{* *} \\
(8.648)\end{array}$ & $\begin{array}{l}-1.302^{* *} \\
(8.329)\end{array}$ & $\begin{array}{l}-1.251^{* *} \\
(8.079)\end{array}$ & $\begin{array}{l}-1.237^{* * *} \\
(7.848)\end{array}$ & $\begin{array}{l}-1.231^{* *} \\
(7.273)\end{array}$ & $\begin{array}{l}-1.229^{* *} \\
(7.157)\end{array}$ \\
\hline Advertisement intensity & $\begin{array}{l}-0.877^{*} \\
(-1.889)\end{array}$ & $\begin{array}{l}-0.877^{*} \\
(-1.889)\end{array}$ & $\begin{array}{l}-0.857^{*} \\
(-1.722)\end{array}$ & $\begin{array}{l}-0.857^{*} \\
(-1.722)\end{array}$ & $\begin{array}{l}-0.857^{\dagger} \\
(-1.629)\end{array}$ & $\begin{array}{l}-0.849^{\dagger} \\
(-1.547)\end{array}$ & $\begin{array}{l}-0.626 \\
(1.209)\end{array}$ & $\begin{array}{l}-0.523 \\
(-1.077)\end{array}$ \\
\hline Trade intensity & $\begin{array}{l}-1.018^{* *} \\
(-3.370)\end{array}$ & $\begin{array}{l}-1.018^{* *} \\
(-3.370)\end{array}$ & $\begin{array}{l}-1.023^{* *} \\
(-3.579)\end{array}$ & $\begin{array}{l}-1.024^{* *} \\
(-3.613)\end{array}$ & $\begin{array}{l}-1.022^{* *} \\
(-3.512)\end{array}$ & $\begin{array}{l}-1.019^{* * *} \\
(-3.439)\end{array}$ & $\begin{array}{l}-1.018^{* *} \\
(-3.370)\end{array}$ & $\begin{array}{l}-1.018^{* *} \\
(-3.370)\end{array}$ \\
\hline Debt-Equity ratio & $\begin{array}{l}-1.126^{* * * *} \\
(-26.434)\end{array}$ & $\begin{array}{l}-1.115^{* * *} \\
(-23.129)\end{array}$ & $\begin{array}{l}-1.114^{* * *} \\
(-22.481)\end{array}$ & $\begin{array}{l}-1.116^{* * * *} \\
(-23.229)\end{array}$ & $\begin{array}{l}-1.107^{* * *} \\
(-20.673)\end{array}$ & $\begin{array}{l}-1.111^{* * *} \\
(-21.841)\end{array}$ & $\begin{array}{l}-1.109^{* * * *} \\
(-21.533)\end{array}$ & $\begin{array}{l}-1.112^{\text {**** }} \\
(-22.227)\end{array}$ \\
\hline Market-capitalization & $\begin{array}{l}-0.352^{*} \\
(-1.835)\end{array}$ & $\begin{array}{l}-0.312^{*} \\
(-1.733)\end{array}$ & $\begin{array}{l}-0.224^{\dagger} \\
(-1.622)\end{array}$ & $\begin{array}{l}-0.209^{\dagger} \\
(-1.553)\end{array}$ & $\begin{array}{l}-0.145 \\
(-1.176)\end{array}$ & $\begin{array}{l}-0.143 \\
(-1.121)\end{array}$ & $\begin{array}{l}-0.125 \\
(-1.041)\end{array}$ & $\begin{array}{l}-0.124 \\
(-1.003)\end{array}$ \\
\hline $\begin{array}{l}\text { NAS to total revenue of } \\
\text { auditor }\end{array}$ & $\begin{array}{l}0.578^{* *} \\
(8.076)\end{array}$ & $\begin{array}{l}0.578^{* *} \\
(8.076)\end{array}$ & $\begin{array}{l}0.578^{* *} \\
(8.076)\end{array}$ & $\begin{array}{l}0.578^{* * *} \\
(8.076)\end{array}$ & $\begin{array}{l}0.578^{* *} \\
(8.076)\end{array}$ & $\begin{array}{l}0.578^{* *} \\
(8.076)\end{array}$ & $\begin{array}{l}0.578^{* *} \\
(8.076)\end{array}$ & $\begin{array}{l}0.578^{* * *} \\
(8.076)\end{array}$ \\
\hline Adjusted $\mathrm{R}^{2}$ & 0.46 & 0.46 & 0.46 & 0.47 & 0.48 & 0.49 & 0.49 & 0.49 \\
\hline N (Firm-Years) & 2376 & 2376 & 2376 & 2376 & 2376 & 2376 & 2376 & 2376 \\
\hline
\end{tabular}

Note: \#OLS estimates are shown in above table (t-statistics appear in parentheses).

$* * * \mathrm{p}<0.001, * * \mathrm{p}<0.01, * \mathrm{p}<0.05$, and $\dagger \mathrm{p}<0.1$ 
Table 5: Association between discretionary accruals and busyness of audit committee members-full sample (Data: 2004-12)

\begin{tabular}{|c|c|c|c|c|c|c|c|c|}
\hline $\begin{array}{l}\text { DA } \\
\text { variable) }\end{array}$ & (a) & (b) & (c) & (d) & (e) & (f) & (g) & (h) \\
\hline & $\begin{array}{l}\text { Spline } \\
\text { Node }=3\end{array}$ & $\begin{array}{l}\text { Spline } \\
\text { Node }=4\end{array}$ & $\begin{array}{l}\text { Spline } \\
\text { Node=5 }\end{array}$ & $\begin{array}{l}\text { Spline } \\
\text { Node=6 }\end{array}$ & $\begin{array}{l}\text { Spline } \\
\text { Node=7 }\end{array}$ & $\begin{array}{l}\text { Spline } \\
\text { Node=8 }\end{array}$ & $\begin{array}{l}\text { Spline } \\
\text { Node=9 }\end{array}$ & $\begin{array}{l}\text { Spline } \\
\text { Node }=10\end{array}$ \\
\hline Intercept & $\begin{array}{l}15.762^{* * * *} \\
(81.629)\end{array}$ & $\begin{array}{l}15.467^{* * *} \\
(76.923)\end{array}$ & $\begin{array}{l}15.401^{* * * *} \\
(75.411)\end{array}$ & $\begin{array}{l}15.353^{* * *} \\
(73.632)\end{array}$ & $\begin{array}{l}15.311^{* * *} \\
(72.392)\end{array}$ & $\begin{array}{l}15.302^{* * *} \\
(70.122)\end{array}$ & $\begin{array}{l}15.113^{* * *} \\
(69.887)\end{array}$ & $\begin{array}{l}14.944^{* * * *} \\
(69.229)\end{array}$ \\
\hline Spline-1 & $\begin{array}{l}0.423 \\
(0.675)\end{array}$ & $\begin{array}{l}0.427 \\
(0.727)\end{array}$ & $\begin{array}{l}0.711 \\
(1.023)\end{array}$ & $\begin{array}{l}1.023^{\dagger} \\
(1.302)\end{array}$ & $\begin{array}{l}1.121^{*} \\
(1.819)\end{array}$ & $\begin{array}{l}1.127^{*} \\
(1.923)\end{array}$ & $\begin{array}{l}1.132^{*} \\
(2.236)\end{array}$ & $\begin{array}{l}1.133^{*} \\
(2.319)\end{array}$ \\
\hline Spline-2 & $\begin{array}{l}-0.949^{\dagger} \\
(-1.532)\end{array}$ & $\begin{array}{l}-0.957^{\dagger} \\
(-1.572)\end{array}$ & $\begin{array}{l}-0.841 \\
(-1.257)\end{array}$ & $\begin{array}{l}-0.816 \\
(-1.221)\end{array}$ & $\begin{array}{l}-0.805 \\
(-1.203)\end{array}$ & $\begin{array}{l}-0.799 \\
(-1.192)\end{array}$ & $\begin{array}{l}-0.799 \\
(-1.192)\end{array}$ & $\begin{array}{l}-0.799 \\
(-1.192)\end{array}$ \\
\hline $\begin{array}{l}\text { Median committee- } \\
\text { board size }\end{array}$ & $\begin{array}{l}0.542 \\
(1.169)\end{array}$ & $\begin{array}{l}0.516 \\
(1.133)\end{array}$ & $\begin{array}{l}0.667 \\
(1.243)\end{array}$ & $\begin{array}{l}1.012^{*} \\
(2.223)\end{array}$ & $\begin{array}{l}1.801^{* *} \\
(5.771)\end{array}$ & $\begin{array}{l}1.722^{* *} \\
(4.561)\end{array}$ & $\begin{array}{l}1.734^{* *} \\
(5.119)\end{array}$ & $\begin{array}{l}1.721^{* *} \\
(4.112)\end{array}$ \\
\hline Board size & $\begin{array}{l}-0.246^{\dagger} \\
(-1.319)\end{array}$ & $\begin{array}{l}-0.297^{\dagger} \\
(-1.452)\end{array}$ & $\begin{array}{l}-0.321^{*} \\
(-2.219)\end{array}$ & $\begin{array}{l}-0.246^{\dagger} \\
(-1.323)\end{array}$ & $\begin{array}{l}-0.221 \\
(-1.119)\end{array}$ & $\begin{array}{l}-0.187 \\
(-0.877)\end{array}$ & $\begin{array}{l}-0.145 \\
(-0.711)\end{array}$ & $\begin{array}{l}-0.123 \\
(-0.619)\end{array}$ \\
\hline $\begin{array}{l}\text { Independent directors } \\
\text { proportion }\end{array}$ & $\begin{array}{l}-1.396^{* *} \\
(5.199)\end{array}$ & $\begin{array}{l}-1.386^{* *} \\
(4.787)\end{array}$ & $\begin{array}{l}-1.396^{* *} \\
(5.199)\end{array}$ & $\begin{array}{l}-1.399^{* *} \\
(5.442)\end{array}$ & $\begin{array}{l}-1.396^{* *} \\
(5.199)\end{array}$ & $\begin{array}{l}-1.395^{* *} \\
(5.112)\end{array}$ & $\begin{array}{l}-1.395^{* *} \\
(5.112)\end{array}$ & $\begin{array}{l}-1.395^{* *} \\
(5.112)\end{array}$ \\
\hline AC chair expertise & $\begin{array}{l}-0.831^{*} \\
(-1.349)\end{array}$ & $\begin{array}{l}-0.877^{*} \\
(-1.889)\end{array}$ & $\begin{array}{l}-0.851^{*} \\
(-1.665)\end{array}$ & $\begin{array}{l}-0.846^{\dagger} \\
(-1.541)\end{array}$ & $\begin{array}{l}-0.846^{\dagger} \\
(-1.541)\end{array}$ & $\begin{array}{l}-0.762 \\
(-1.188)\end{array}$ & $\begin{array}{l}-0.653 \\
(-1.065)\end{array}$ & $\begin{array}{l}-0.637 \\
(-1.027)\end{array}$ \\
\hline R\&D intensity & $\begin{array}{l}-1.030^{* *} \\
(8.248)\end{array}$ & $\begin{array}{l}-1.022^{* *} \\
(7.901)\end{array}$ & $\begin{array}{l}-1.017^{* *} \\
(7.447)\end{array}$ & $\begin{array}{l}-1.016^{* *} \\
(6.931)\end{array}$ & $\begin{array}{l}-1.011^{* *} \\
(6.551)\end{array}$ & $\begin{array}{l}-1.009^{* *} \\
(6.448)\end{array}$ & $\begin{array}{l}-1.007^{* *} \\
(6.319)\end{array}$ & $\begin{array}{l}-1.007^{* *} \\
(6.319)\end{array}$ \\
\hline Advertisement intensity & $\begin{array}{l}-0.857^{\dagger} \\
(-1.629)\end{array}$ & $\begin{array}{l}-0.849^{\dagger} \\
(-1.547)\end{array}$ & $\begin{array}{l}-0.661 \\
(-1.242)\end{array}$ & $\begin{array}{l}-0.603 \\
(-1.037)\end{array}$ & $\begin{array}{l}-0.603 \\
(-1.037)\end{array}$ & $\begin{array}{l}-0.601 \\
(-0.842)\end{array}$ & $\begin{array}{l}-0.576 \\
(-0.676)\end{array}$ & $\begin{array}{l}-0.576 \\
(-0.676)\end{array}$ \\
\hline Trade intensity & $\begin{array}{l}-0.657^{\dagger} \\
(-1.432)\end{array}$ & $\begin{array}{l}-0.626^{\dagger} \\
(-1.301)\end{array}$ & $\begin{array}{l}-0.601 \\
(-1.165)\end{array}$ & $\begin{array}{l}-0.587 \\
(-1.114)\end{array}$ & $\begin{array}{l}-0.544 \\
(-1.025)\end{array}$ & $\begin{array}{l}-0.521 \\
(-0.972)\end{array}$ & $\begin{array}{l}-0.517 \\
(-0.923)\end{array}$ & $\begin{array}{l}-0.513 \\
(-0.905)\end{array}$ \\
\hline Debt-Equity ratio & $\begin{array}{l}-0.432^{* *} \\
(-6.434)\end{array}$ & $\begin{array}{l}-0.419^{* *} \\
(-5.117)\end{array}$ & $\begin{array}{l}-0.265^{*} \\
(-2.167)\end{array}$ & $\begin{array}{l}-0.129 \\
(-1.174)\end{array}$ & $\begin{array}{l}-0.126 \\
(-1.014)\end{array}$ & $\begin{array}{l}-0.123 \\
(-1.002)\end{array}$ & $\begin{array}{l}-0.123 \\
(-1.002)\end{array}$ & $\begin{array}{l}-0.123 \\
(-1.002)\end{array}$ \\
\hline Market-capitalization & $\begin{array}{l}-0.047^{\dagger} \\
(-1.635)\end{array}$ & $\begin{array}{l}-0.042^{\dagger} \\
(-1.533)\end{array}$ & $\begin{array}{l}-0.034 \\
(-1.222)\end{array}$ & $\begin{array}{l}-0.031 \\
(-1.115)\end{array}$ & $\begin{array}{l}-0.028 \\
(-1.009)\end{array}$ & $\begin{array}{l}-0.028 \\
(-1.009)\end{array}$ & $\begin{array}{l}-0.028 \\
(-1.009)\end{array}$ & $\begin{array}{l}-0.028 \\
(-1.009)\end{array}$ \\
\hline $\begin{array}{l}\text { NAS to total revenue of } \\
\text { auditor }\end{array}$ & $\begin{array}{l}0.082^{*} \\
(2.176)\end{array}$ & $\begin{array}{l}0.066^{\dagger} \\
(1.626)\end{array}$ & $\begin{array}{l}0.047 \\
(1.222)\end{array}$ & $\begin{array}{l}0.047 \\
(1.222)\end{array}$ & $\begin{array}{l}0.047 \\
(1.222)\end{array}$ & $\begin{array}{l}0.047 \\
(1.222)\end{array}$ & $\begin{array}{l}0.047 \\
(1.222)\end{array}$ & $\begin{array}{l}0.047 \\
(1.222)\end{array}$ \\
\hline Adjusted $\mathrm{R}^{2}$ & 0.56 & 0.59 & 0.59 & 0.57 & 0.60 & 0.59 & 0.59 & 0.59 \\
\hline N (Firm-Years) & 3733 & 3733 & 3733 & 3733 & 3733 & 3733 & 3733 & 3733 \\
\hline
\end{tabular}

Note: \#OLS estimates are shown in above table (t-statistics appear in parentheses).

$* * * \mathrm{p}<0.001, * * \mathrm{p}<0.01, * \mathrm{p}<0.05$, and $\dagger \mathrm{p}<0.1$ 
Table 6: Association between discretionary accruals and busyness of audit committee members-summary findings full sample (Data: 2004-12)

\begin{tabular}{|l|l|l|}
\hline Effect of AC Busyness on & Bad Effects (agency theory) & Good Effects (resource-dependence theory) \\
\hline Foreign Firms (585 firm-years) & $\geq 6$ & None \\
\hline Government Firms (772 firm-years) & $\geq 6$ & $\leq 5$ \\
\hline Local Private Firms (2376 firm-years) & $\geq 5$ & None \\
\hline Overall Sample (3733firm-years) & $\geq 6$ & $\leq 4$ \\
\hline
\end{tabular}

